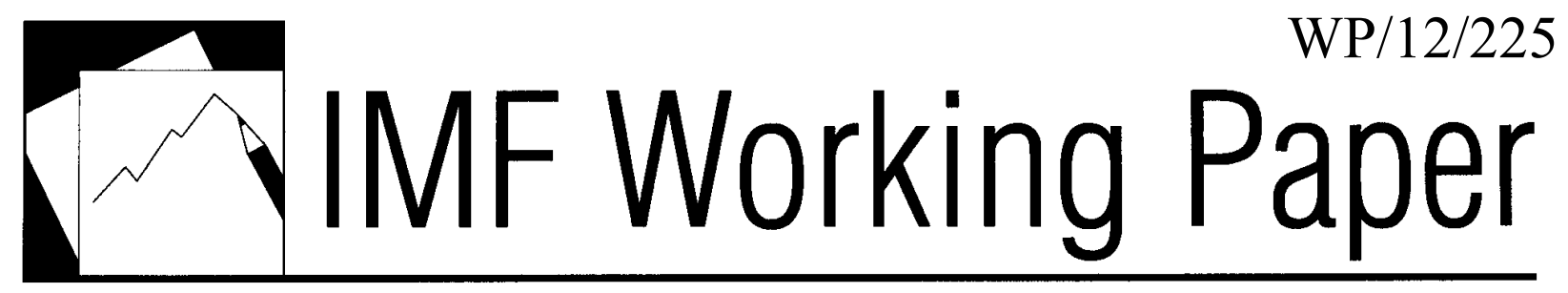

\title{
Inflation Responses to Commodity Price Shocks- How and Why Do Countries Differ?
}

Gaston Gelos and Yulia Ustyugova 


\title{
IMF Working Paper
}

Institute for Capacity Development and Western Hemisphere Department

\author{
Inflation Responses to Commodity Price Shocks - How and Why Do Countries Differ? \\ Prepared by Gaston Gelos and Yulia Ustyugova* \\ Authorized for distribution by Marco Piñón
}

September 2012

\begin{abstract}
This Working Paper should not be reported as representing the views of the IMF. The views expressed in this Working Paper are those of the author(s) and do not necessarily represent those of the IMF or IMF policy. Working Papers describe research in progress by the author(s) and are published to elicit comments and to further debate.
\end{abstract}

\begin{abstract}
This paper relates the inflationary impact of commodity price shocks across countries to a broad range of structural characteristics and policy frameworks over the period 2001-2010, using several approaches. The analysis suggests that economies with higher food shares in CPI baskets, fuel intensities, and pre-existing inflation levels were more prone to experience sustained inflationary effects from commodity price shocks. Countries with more independent central banks and higher governance scores seem to have contained the impact of these shocks better. The effect of the presence of inflation targeting regimes, however, appears very modest and not evident during the 2008 food price shock. The evidence suggests that trade openness, financial development, dollarization, and labor market flexibility do not significantly influence the way in which domestic inflation responds to international commodity price shocks.
\end{abstract}

JEL Classification Numbers: E31, F41, E50, E52, E60

Keywords: inflation, commodity prices, pass-through, Phillips curve Authors’ E-Mail Addresses: ggelos@,imf.org; yustyugova@imf.org

\footnotetext{
*The authors would like to thank Mario Catalán, Mancini Griffoli, Dalia Hakura, Ruy Lama, Erlend Nier, Maxym Kryshko, Sam Ouliaris, Jorge Restrepo, Juan Pablo Medina, Marcel Fratzscher and participants of the Central Bank of Turkey/IMF conference "Policy Responses to Commodity Price Movements" for their useful comments.
} 
I. Introduction and Summary ................................................................................

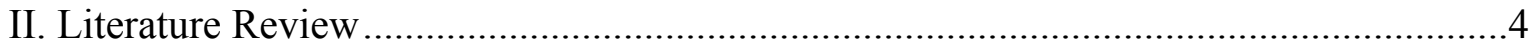

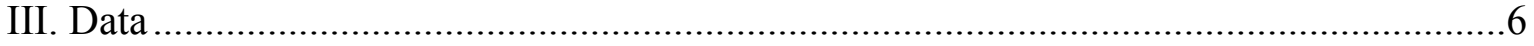

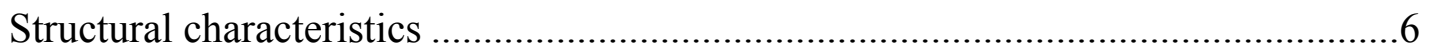

Monetary and exchange-rate regimes............................................................... 7

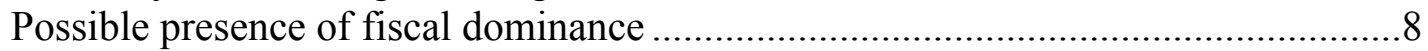

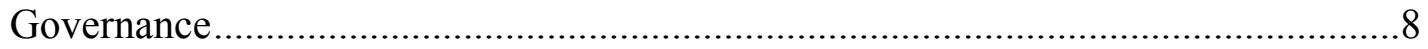

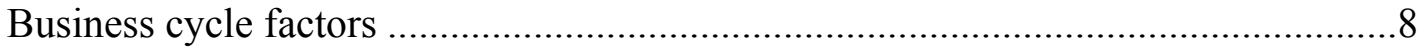

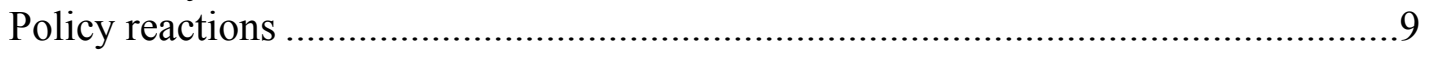

IV. Does Inflation Revert to Core Inflation or Vice Versa? ...........................................9

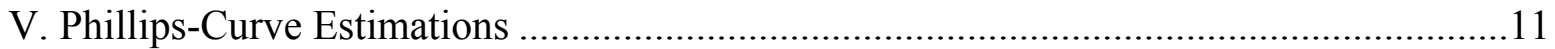

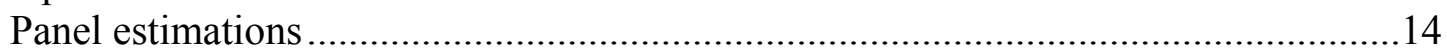

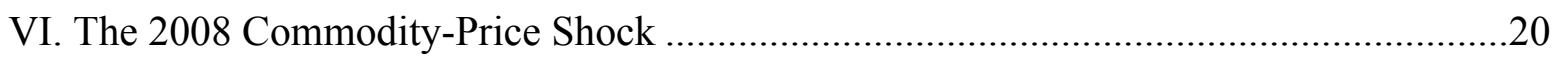

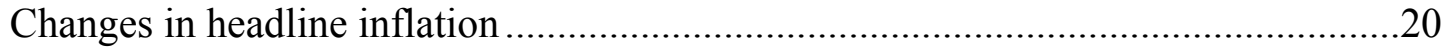

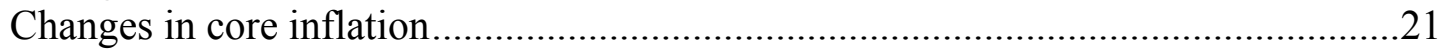

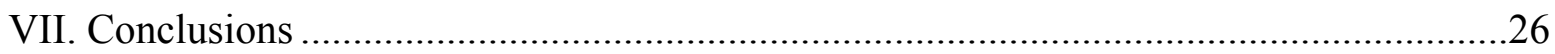

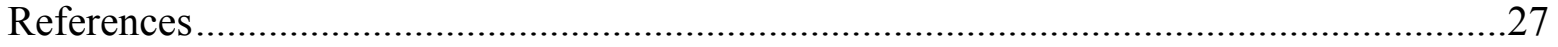

Tables

1. Phillips Curves-Panel Estimations ..................................................................... 18

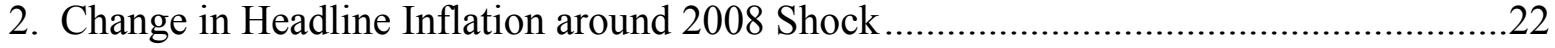

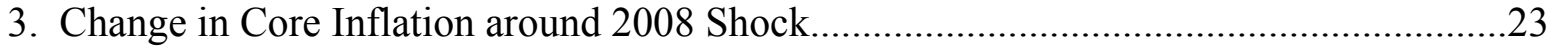

Appendices

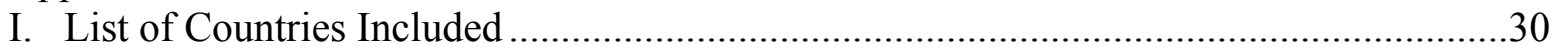

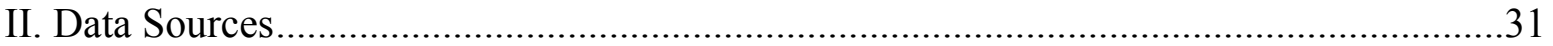




\section{INTRODUCTION AND SUMMARY}

In the current environment of economic slowdown and uncertainty, high commodity prices and their swings have posed a complex challenge to policymakers striving to find the appropriate policy response. They have also brought a broader question to the forefront of the discussion: which structural characteristics and policy frameworks help economies contain the inflationary effects from commodity price shocks? To date, surprisingly little systematic research has been conducted on this issue.

One attempt can be found in the IMF's World Economic Outlook (IMF, 2011) which examines the impact of commodities prices on inflation in a broad set of countries. ${ }^{1}$ However, the analysis stops at assessing that "commodity prices tend to have stronger and longer-lasting effects on inflation in economies with high food shares in the consumption basket and in economies with less firmly anchored expectations."

Here, we go further in various dimensions. We explore questions such as: Did countries with more independent central banks or inflation-targeting regimes experience lower passthroughs of commodity price shocks to domestic, including core inflation? What is the role of the openness of the economy and the development of its financial sector in the transmission of international price shocks? How important is the pre-existing level of inflation in determining the pass-through? To which extent does a country's governance framework - beyond the institutional features of the monetary regime - matter in containing the impact on inflation? What role does exchange-rate flexibility play? We examine these questions in a comprehensive way using data for both advanced and developing economies over the period 2001-2011.

We use several approaches to assess the impact of commodity price shocks on inflation. First, we assess the speeds at which headline inflation reverts to core inflation in advanced and developing economies, and relate these adjustment speeds to country characteristics and policy frameworks. Next, we estimate pass-throughs of international food and fuel prices to domestic inflation using both country-by-country estimations and panel estimations of augmented Phillips curves, relating the size of the pass-throughs to country variables. Finally, we study the cross-country performance of headline and core inflation around the large 2008 commodity price shock. One methodological innovation is that we explicitly examine the role of the dispersion of survey forecasts of inflation (as a measure of inflation uncertainty).

In line with conventional wisdom, we find that commodity price shocks have stronger effects on domestic inflation in developing countries than in advanced economies. For example, the median long-term pass-through of a food price shock to domestic inflation is about four times larger for emerging and developing economies than for advanced economies. For the fuel price pass-though, the difference in the median values is less dramatic, but the dispersion of

\footnotetext{
${ }^{1}$ See also IMF (2008) and Habermeier et al (2009).
} 
the pass-throughs for developing economies is significantly larger. This could reflect variations in the use of price controls and subsidies in these countries. Not surprisingly, we also find that economies with a high weight of food in the CPI basket and high oil intensities are more prone to experience stronger inflationary effects from food and fuel price shocks.

What does come as a surprise is that some other factors do not seem to affect the inflation response to commodity price shocks the way economic theory predicts. Neither financial development nor financial dollarization appears to significantly influence the way to which domestic inflation responds to international price shocks. We could not document a statistically significant relationship between labor market flexibility and the pass-through of commodity price shocks to domestic inflation, either. Similarly, the degree of trade openness is not generally related to the size of the pass-through. However, there is some indication that fuel price dynamics have a higher effect on domestic prices in more open developing economies.

There is clear evidence that the inflationary impact of a commodity shock is higher for higher pre-existing inflation levels. In addition, there is some indication that a larger dispersion of inflation expectations is associated with higher inflationary pass-throughs, but the evidence is mixed and deserves to be examined further.

Interestingly, while we find some indication that inflation targeting countries fared better in their inflation response to shocks, the effect is very modest. ${ }^{2}$ Moreover, the data suggest that around the large 2008 food price shock, inflation targeters were not more able than other countries to prevent a pass-through of commodity price shocks to core inflation, even when controlling for other factors.

However, this does not mean that monetary policy credibility does not matter: countries with more independent central banks and higher governance scores - proxies for policy credibility - seem to have better contained the impact of commodity shocks.

\section{LITERATURE REVIEW}

The studies that assess the impact of commodity shocks on inflation use a variety of approaches that differ significantly in scope, choice of control variables, and estimation techniques. Not surprisingly, the results also differ, as summarized below.

The IMF's World Economic Outlook (IMF, 2011) discusses the adequate monetary policy response to commodity price shocks and examines the impact of these shocks on inflation in a broad set of countries over the period 2000-2011. The pass-through analysis is based on country-by-country regressions of domestic food or transportation price inflation on international commodity inflation and lagged domestic food or transportation inflation. It

\footnotetext{
2 This is in contrast to early findings by Habermeier et al (2009). See Brito and Bystedt (2010) for a recent study finding only weak effects of inflation targeting on inflation performance.
} 
reports that food price shocks tend to have larger effects on headline inflation in emerging and developing economies than in advanced economies. ${ }^{3}$ The impact is larger and longer lasting in economies with high food shares in consumption. Moreover, because medium-term inflation expectations are weakly anchored in many emerging and developing economies, food price shocks have larger effects on inflation expectations in these economies. The analysis in the World Economic Outlook, however, does not attempt to assess systematically the role of other country characteristics in shaping the response of headline inflation.

Habermeier et al. (2009) provide an early assessment of the impact of the food and oil price shock for developing and emerging countries prior to the global financial crisis. Covering data from 2007 through June 2008 and using panel estimations, they explore the underlying causes of inflation across 50 countries and analyze the monetary policy response. The analysis suggests that while the official inflation targets were overshot by most emerging economies with inflation targeting (IT) frameworks, IT countries have managed to counter inflation better. The authors also find evidence that exchange rate policy, together with higher central bank independence and transparency were associated with lower inflation. The effect of monetary tightening aimed at containing inflation pressures, however, was limited.

De Gregorio, Landerretche, and Neilson (2008) present evidence of a decline during recent decades in the pass-through from the price of oil to the general price level. Their methodology employs Phillips curve and rolling vector autoregression estimations. In a sample of 34 countries, the fall in the pass-through is documented to have been more pronounced in industrial than in emerging economies. The analysis shows that among the factors that might help to explain this decline, the most important are a reduction in the oil intensity of economies around the world, a reduction in the exchange rate pass-through, a more favorable inflation environment, and the fact that the current oil price shock is largely the result of strong world demand.

Another study that is somewhat related to ours is Neely and Rapach (2011). Using a dynamic latent factor model, they examine the role of world, regional, and idiosyncratic components in explaining international comovements in inflation rates across 64 countries. Their results show that world and regional components account for 35 percent and 16 percent of annual inflation variability, respectively. At the country level, they report that openness to trade, institutional quality, financial development, real GDP per capita, average inflation, inflation volatility and central bank independence are correlated with countries' sensitivity to the world factor.

Zoli (2009) assesses the role of international commodity prices, cyclical fluctuations, and convergence in driving inflation in 18 European emerging economies. Using country-specific

\footnotetext{
${ }^{3}$ In an earlier study, the IMF (2008) reported similar findings, with the pass-through from international commodity prices to domestic prices higher for emerging economies, and comparable in size to that for advanced economies in the 1970s.
} 
vector autoregressive models and panel estimates, she finds that international commodity price shocks have a significant impact on domestic inflation, but the inflation response is asymmetric for positive and negative shocks.

Examining data for 19 countries, Cecchetti and Moessner (2008) find that in recent years core inflation has not tended to revert to headline, which suggests that higher commodity prices have generally not spawned strong second-round effects on inflation. However, since the examined period covers 1994 through August 2008, it does not fully include the impact of the commodity price shock that peaked in mid-2008.

Focusing on 19 industrialized countries, Chen (2009) uses a state space approach to estimate time-varying oil price pass-through coefficients. The paper finds a significant decline in the average pass-through and attributes this to changes in monetary policy, the behavior of nominal exchange rates, and higher trade openness. The analysis, however, did not find evidence that a lower inflation environment is associated with lower pass-through.

Rigobón (2010) uses micro price data to examine the pass through of commodity prices for 50 countries. He finds that countries respond differently to shocks and that sectors respond differently across countries and commodities. A third of all the explained variation is driven by sectoral characteristics.

Pedersen (2010) assesses the propagation of food and energy prices shocks in 46 countries for the period 1999-2010 using structural VAR models. His results indicate that in general, the propagation effect of food price shocks is larger than that of energy price shocks, and that emerging economies are more affected by propagation than advanced ones.

\section{DATA}

Our dataset comprises 31 advanced and 61 emerging and developing economies (see Appendix I). The country classification follows the IMF's World Economic Outlook. Below we list the structural characteristics and policy variables included into the dataset and briefly describe the rationale for exploring their role in shaping the inflation response to commodity price shocks.

\section{Structural characteristics: ${ }^{4}$}

- $\quad$ Trade openness. Romer (1993) documents a robust negative relationship across countries between a country's openness to trade and its long-run inflation rate. $\mathrm{He}$ argues that less open countries have more incentives to generate surprise inflation, and therefore greater openness is associated with lower inflation. Subsequent studies,

\footnotetext{
${ }^{4}$ While the share of non-tradable goods in domestic CPI baskets could also affect the pass-through of international commodity price inflation to domestic inflation (Burnstein et al.(2007)), we do not include this factor in the analysis due to limited data availability.
} 
however, have produced mixed results, giving rise to an empirical puzzle (i.e. Terra (1998), Kim and Beladi (2005)).

- Net exporters/importers of commodities. When the commodity price increases, a net food/oil exporter experiences a positive terms of trade shock. This prompts an increase in demand and upward pressure on prices and the nominal exchange rate. The opposite is true for a net importer.

- $\quad$ Food and transport weights in the CPI basket. Higher weights of food and transport in the CPI basket mechanically imply a higher inflationary impact. Moreover, if the share of these goods in the consumption basket is higher, second-round effects are also likely to be larger. ${ }^{5}$

- $\quad$ Fuel intensity. The impact of an increase in oil prices on the general price level can be expected to be positively correlated with the fuel intensity of an economy.

- Degree of financial dollarization. The conventional view is that a high degree of financial dollarization, defined as the holding by residents of foreign currency assets and liabilities, is likely to limit the effectiveness of monetary policy. High financial dollarization is also likely to be associated with a higher degree of indexation in an economy.

- $\quad$ Financial development. Higher financial development is generally thought to be associated with a higher effectiveness of monetary policy. ${ }^{6}$ With more developed financial markets, it may therefore be easier for monetary policy to dampen the inflationary pressures following a commodity price shock.

- Labor market flexibility. Low labor market flexibility is likely to be associated with real wage rigidities which make inflation stabilization more costly in terms of output. Therefore, in the presence of labor market rigidities, the optimal monetary policy in response to an increase in world commodity prices will imply some accommodation of inflation. Thus, it can be expected that countries with more flexible labor markets experience lower inflation pressures stemming from commodity price shocks (Blanchard and Galí, 2007).

\section{Monetary and exchange-rate regimes:}

- $\quad$ Central bank autonomy. In line with the traditional arguments, greater central bank autonomy is associated with higher credibility of monetary policy, which facilitates price stability.

- $\quad$ IT regime. Similarly, inflation targeting regimes are generally seen as improving monetary policy credibility, helping to anchor inflation expectations. Thus, it could be expected that domestic inflation responds less to external commodity price shocks under such regimes.

\footnotetext{
${ }^{5}$ Given limited data availability for domestic fuel prices for a wide sample of countries, we restrict our attention to the weight of transport in CPI basket.

${ }^{6}$ The evidence on this is, however, ambiguous. See Saizar and Chalk (2009).
} 
- $\quad$ Exchange rate flexibility. For net commodity exporters, a rise in commodity prices implies an equilibrium appreciation of the real exchange rate. If the nominal exchange rate is not allowed to appreciate, pressures on domestic prices will be higher. For net importers, a fixed nominal exchange rate will make the required depreciation more difficult but also dampen the inflationary impact.

- $\quad$ The level of inflation. The pass-through is likely to be higher in a high inflation environment. As argued by Taylor (2000), the extent to which firms respond to increases in costs or other prices by raising their own price depends on how persistent the increase is expected to be. Low and more stable inflation should be associated with a less persistent inflationary impact of commodity price shocks.

\section{Possible presence of fiscal dominance:}

- $\quad$ Public debt/GDP. In the presence of fiscal dominance, it will be difficult for monetary policy to achieve its inflation objectives. More generally, there is evidence that fiscal variables tend to influence inflation expectations in emerging markets. ${ }^{7}$

\section{Governance:}

- Index of monetary policy transparency. Greater transparency is associated with higher predictability, better governance and accountability. Therefore, more transparency in monetary policymaking can be expected to help anchor expectations and prevent second-round effects.

- Index of governance and rule of law. Higher values of this index imply higher accountability, transparency, public sector efficiency, and rule of law. While not directly measuring the credibility of monetary policy, it encompasses credibility of institutions and policies overall.

- $\quad$ Regulatory quality. Similar arguments apply to this measure.

\section{Business cycle factors:}

- $\quad$ Output gap. The output gap is often included as a measure of excess demand in Phillips curve analysis. The inflationary impact of an external shock is likely to be higher with a smaller output gap.

\footnotetext{
${ }^{7}$ See Celasun, Gelos, and Prati (2004).
} 


\section{Policy reactions:}

Clearly, apart from the structural characteristics of the economy, the government's policy track record and the institutional framework, the actual policies pursued in response to commodity price shocks should obviously matter. While the appropriate policy response to commodity price shocks is beyond the scope of this study, in some estimations we control for the roles of:

- $\quad$ Nominal effective exchange rate changes.

- $\quad$ Structural fiscal balance and changes therein.

- $\quad$ Short-term interest rates and changes therein.

- Growth of monetary aggregates.

Since data availability differs across countries, so does country coverage in the estimations. For more details on the variables, see Appendix II.

\section{DOES INFLATION REVERT TO CORE INFLATION OR VICE VERSA?}

We start by analyzing the inflation dynamics across the countries in the context of commodity price developments of 2001-2010. Naturally, the inflation rates of the countries were also affected by a number of domestic factors, but the prominent food and energy price swings were among the major common driving forces of inflation globally. Following Cecchetti and Moessner (2008) and Clark (2001), we assess the dynamics of headline inflation with respect to core inflation across advanced and emerging and developing economies. If headline inflation reverted quickly to core inflation, then the impact of international food and energy price shocks was temporary, and second-round effects were probably limited. Otherwise, commodity price developments call for particularly close attention from policymakers.

We estimate the following regression for advanced and emerging and developing economies for the period 2001-2010 using 12-month monthly CPI headline and core inflation.

$$
\pi_{t}^{\text {headline }}-\pi_{t-12}^{\text {headline }}=\alpha+\beta\left(\pi_{t-12}^{\text {headline }}-\pi_{t-12}^{\text {core }}\right)+\varepsilon_{t}
$$

If headline inflation reverts to core, $\beta$ is expected to be negative.

We find that in most cases the estimated betas are indeed negative and statistically different from zero, which corresponds to headline inflation reverting to core. The speeds of reversion of headline inflation to core vary across the groups of countries: the coefficients tend to be smaller for advanced countries (mean=-1.1, median=-1.2) than for emerging and developing countries (mean=-0.8, median=-0.9.) In other words, headline inflation in advanced economies has been reverting to core faster. Moreover, once we compare the estimated 
coefficients for the periods of 1990-2000 and 2001-2010, we find that the coefficients for the advanced countries tended to become smaller. Data restrictions, however, did not allow us to draw definite conclusions on a similar evolution of the coefficients for the developing economies.

Advanced Economies, 2001-2010

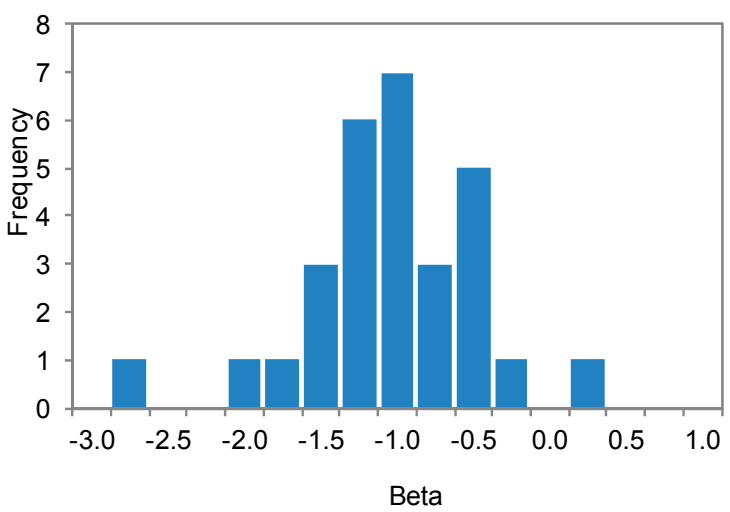

Emerging and Developing Economies, 2001-2010

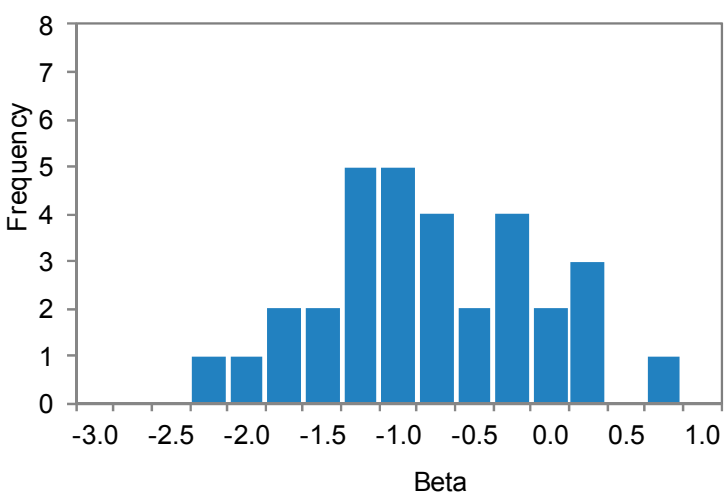

Given the differences in the estimated speeds of reversion of headline inflation to core, we tested whether there are any correlations between key institutional and macroeconomic characteristics of economies and the speeds of the reversion. However, we did not find much evidence of such correlations. There is some evidence that larger food weight in CPI basket (as one may expect) and higher degree of exchange rate stability were associated with a lower reversion speed of headline to core inflation. Other institutional and macroeconomic characteristics, such as trade openness, the degree of financial dollarization, financial development, labor market flexibility, the presence of an inflation targeting regime, the degree of central bank autonomy, governance and public debt, were not significantly correlated with the speed of reversion. Even when we controlled for the development levels of countries (advanced vs. emerging/developing economies) and examined the correlations over shorter periods of time, the results remained inconclusive. This may be caused by the omitted variables problem that we try to address further in the paper.

Headline inflation reverting to core, however, is only one part of the story about the behavior of inflation. It is also interesting to assess whether core inflation reverted to headline inflation. If this were the case, it would indicate that shocks to headline inflation, such as those caused by commodity price spikes, would feed into inflation expectations and price setting, fueling core inflation and raising a red flag for the policymakers. To study this issue, we run a regression similar to one estimated before:

$\pi_{t}^{\text {core }}-\pi_{t-12}^{\text {core }}=\omega+\delta\left(\pi_{t-12}^{\text {core }}-\pi_{t-12}^{\text {headline }}\right)+\varepsilon_{t}$

If $\delta$ is equal to 0 , core does not revert to headline inflation, whereas a coefficient of -1 implies full reversion. 
We can see from the charts below that for some countries the estimated deltas were close to zero: for 25 out of 62 countries we failed to reject the hypothesis that core inflation is not reverting to headline. ${ }^{8}$ However for many countries the evidence suggests the worrisome presence of second-round effects.
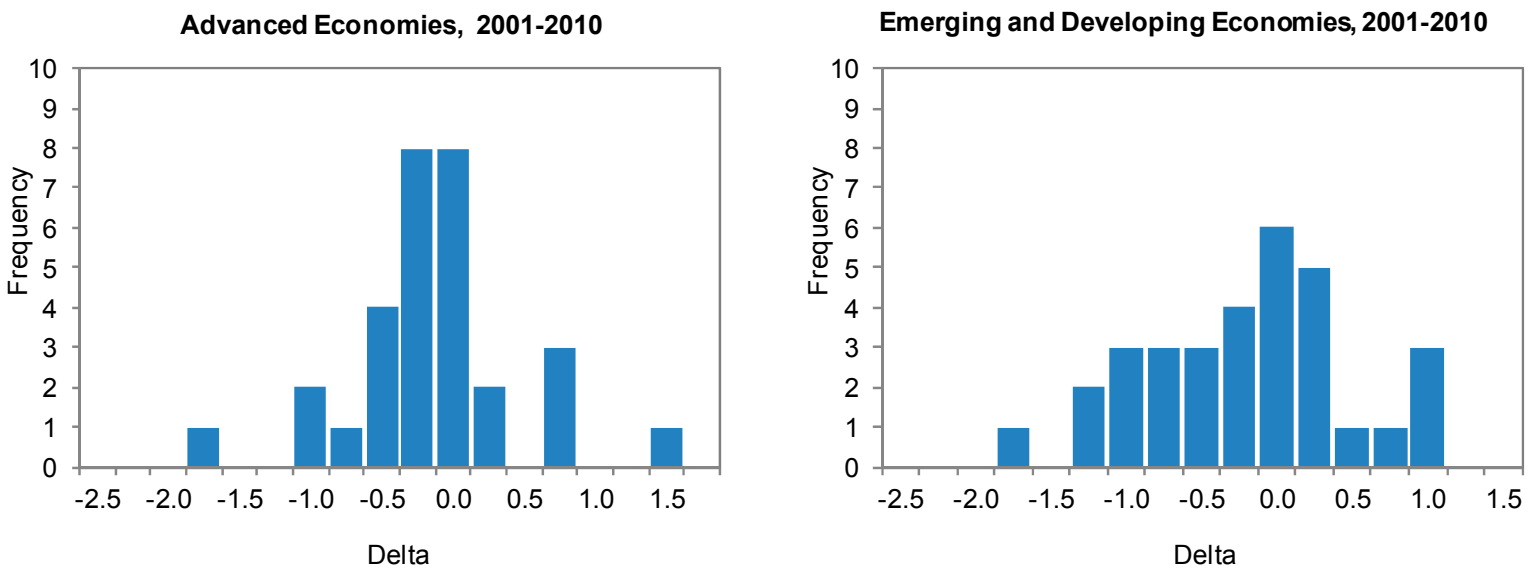

Thus, although in 2001-2010 headline inflation generally tended to revert to core, we find evidence of second-round effects in both advanced and emerging economies. We now turn to examining directly how exactly commodity price shocks affected domestic inflation across the countries.

\section{Phillips-Curve Estimations}

We estimate country-by-country Phillips curves augmented by commodity prices for the period 2001-2010, broadly following Hooker (2002) and De Gregorio, Landerretche, and Neilson (2008). ${ }^{9}$ The dependent variable is 12 -month monthly CPI headline inflation ${ }^{10}$, and the independent variables encompass lagged values of inflation to capture inertia in the inflation process, the current and lagged values of the output gap as a measure of economic slack, and international food and fuel prices. ${ }^{11}$ For each country, we select the lag length

\footnotetext{
${ }^{8}$ These 25 countries include both advanced and emerging and developing economies.

${ }^{9}$ See also Borio and Filardo (2007).

${ }^{10} \mathrm{We}$ choose to focus on headline inflation rather than core inflation since most of the central banks set their targets in terms of headline inflation.

${ }^{11}$ Typically, commodity price inflation included into Phillips curves measures the changes in commodity prices denominated in foreign currency. We estimate specifications with food prices expressed both in U.S. dollars and converted to domestic currency to account for variations in the exchange rates. The reported results refer to the ones obtained by using dollar-denominated prices (unless otherwise marked) but the main conclusions are common to both specifications.
} 
minimizing the Akaike-criterion. Given the serial correlation induced by overlapping observations, we compute the standard errors with the Newey-West estimator ${ }^{12}$.

$\pi_{t}=\alpha+\sum_{i=1}^{n} \delta_{t-i} \pi_{t-i}+\sum_{i=0}^{m} \phi_{t-i}$ OutputGap ${ }_{t-i}+\sum_{i=0}^{p} \theta_{t-i} \pi_{t-i}^{\text {WorldFood }}+\sum_{i=0}^{q} v_{t-i} \pi_{t-i}^{\text {WorldFuel }}+\varepsilon_{t}$

The pass-throughs are then calculated as $P T_{\text {food }}=\frac{\sum_{i=0}^{p} \theta}{1-\sum_{i=1}^{n} \delta}$, and $P T_{\text {fuel }}=\frac{\sum_{i=0}^{q} v}{1-\sum_{i=1}^{n} \delta} \cdot{ }^{13}$

As expected, and in line with results reported in IMF (2011), we find that commodity price shocks have stronger effects on domestic inflation in developing countries than in advanced economies (see charts below). For example, the median long-term pass-through of a 10 percentage point food price shock to domestic inflation for advanced economies is 0.2 percentage points, and about four times larger for emerging and developing economies. For the fuel price pass-though, the difference in the median values between advanced and emerging and developing economies is less dramatic, but the dispersion of the pass-through for developing economies is significantly larger. This could reflect the use of price controls and subsidies in some of these countries. The results are qualitatively very similar for passthroughs of food and fuel price inflation denominated in domestic currency.
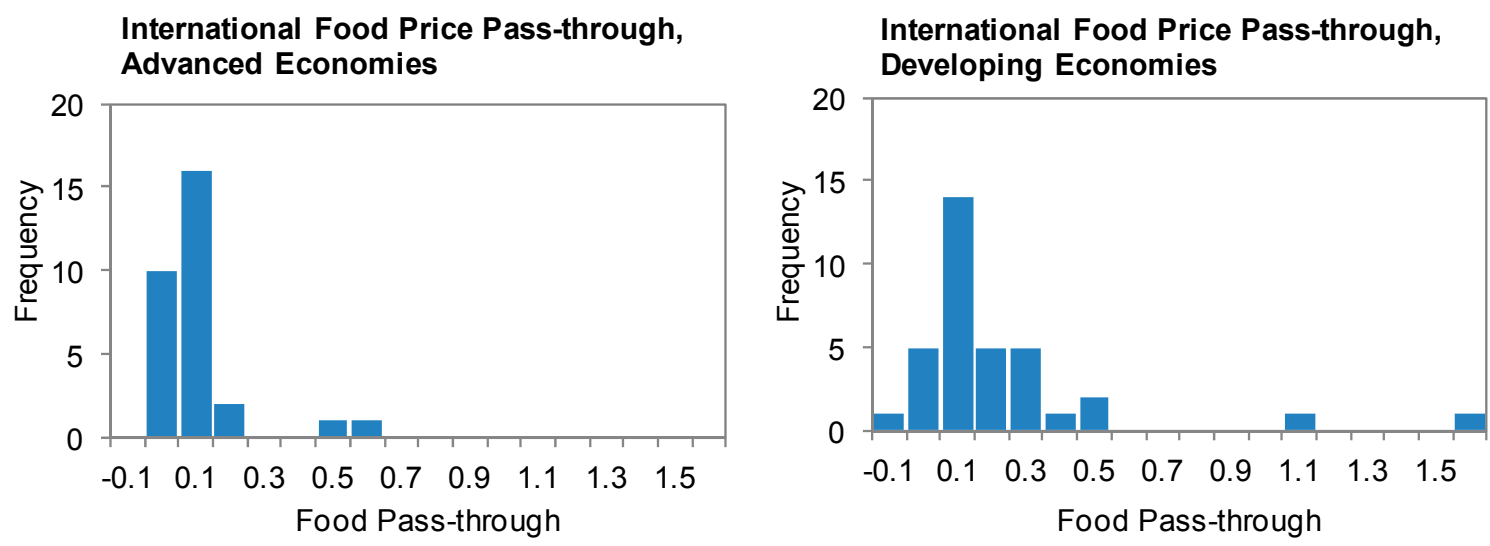

\footnotetext{
${ }^{12}$ We treat the series as stationary on economic and statistical grounds. So Im et al. (2010) provide strong evidence that world-wide inflation rates are stationary.

${ }^{13}$ Strictly speaking, these pass-throughs represent the effect of a permanent change in oil and food price inflation on CPI inflation. While this may not be conceptually the right measure one would like to obtain, it represents a good proxy for the size of the transmission of international price shocks in the absence of cointegrating relationships between price levels. See also IMF (2011).
} 

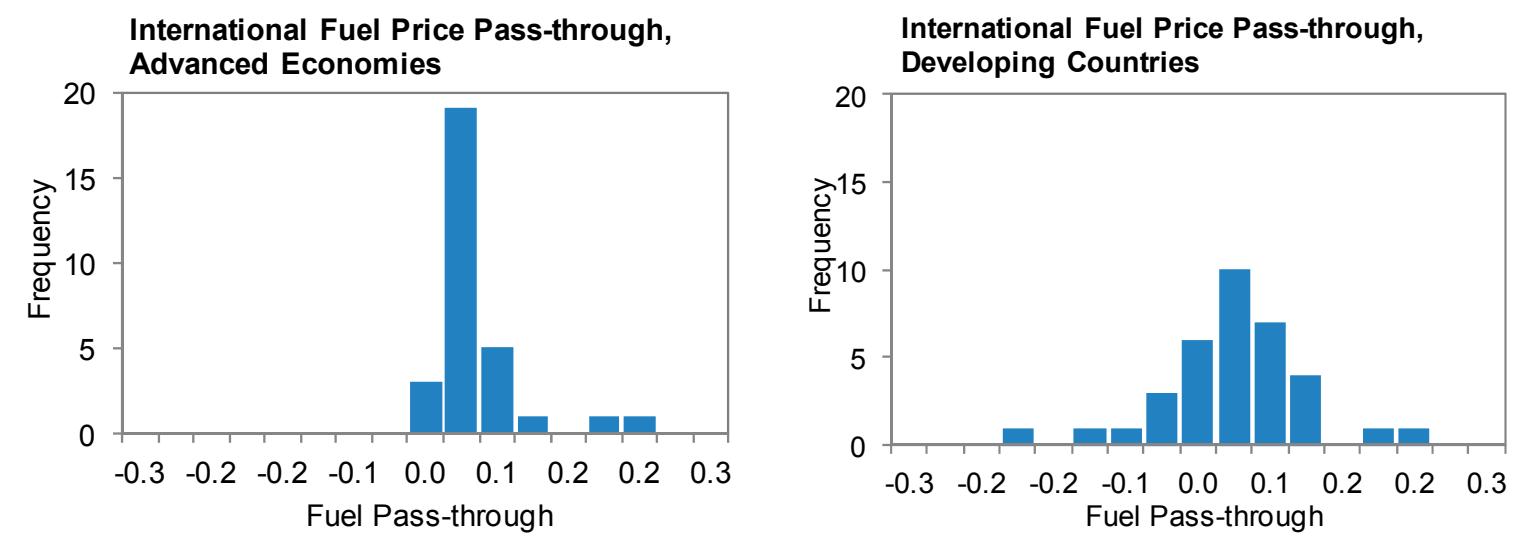

Next, we turn to analyzing how country factors affect the pass-through from international commodity prices to domestic prices. To relate the size of the estimated pass-throughs to the key country characteristics and policy frameworks, we examine simple bivariate scatter plots and estimate bivariate regressions. ${ }^{14}$

We find that countries with certain structural characteristics are more prone to experience sustained inflationary effects from food and fuel price shocks. These characteristics include a high weight of food in the CPI basket and trade openness of the economy (both correlations are particularly strong for the developing economies). These results came as no surprise, being consistent with the findings of other empirical studies of this topic. There is also some indication that the economies with a higher level of dollarization are more affected by the international food price shocks.

In addition, we find that higher central bank autonomy and better governance are associated with a smaller impact of commodity price shocks. However, the correlation between central bank autonomy and pass-throughs is less apparent when
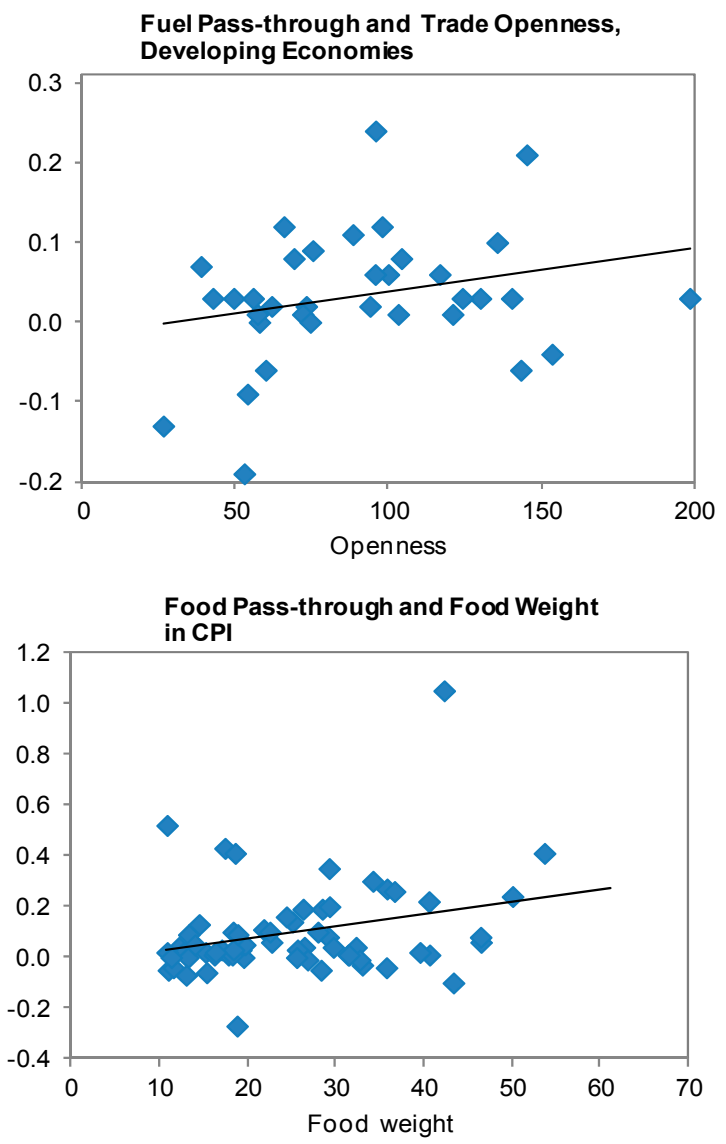
international food price shocks are measured in foreign currency.

\footnotetext{
${ }^{14}$ We do not show the results for the bivariate regressions, but discuss the key results in the text.
} 
As expected, higher uncertainty about inflation as measured by a higher standard deviation of survey inflation expectations (from Consensus Forecasts) is associated with a larger pass-through of international food price shocks. ${ }^{15}$ However, this correlation is less clear with pass-throughs of food price inflation measured in foreign currency.

Importantly, only food weight, governance, and central bank autonomy are significantly correlated with the size of the pass-throughs measured in foreign and domestic currencies.

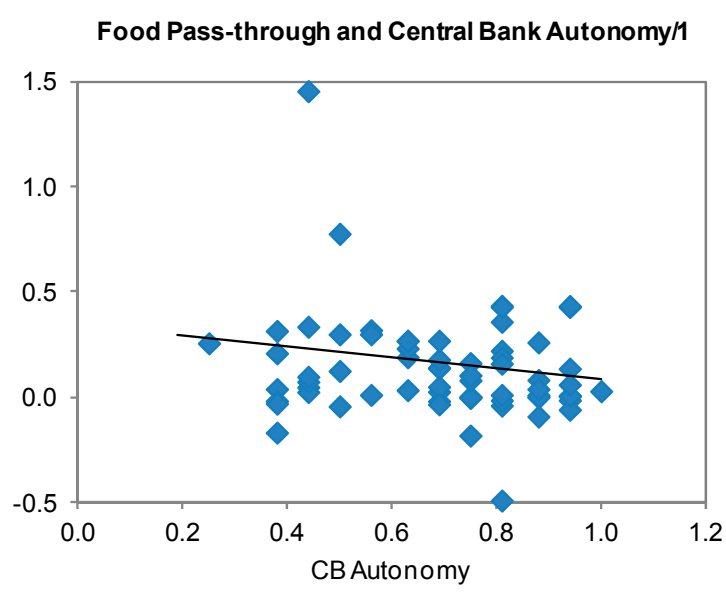

As for the other variables, there is surprisingly little correlation with the pass-throughs. In particular, there is little indication that inflation-targeting countries have lower passthroughs.

\section{Panel estimations}

While country-by-country estimations presented so far have the advantage of not imposing constraints across countries, they also entail limitations since they only allow for a limited, cross-sectional analysis of the relation between the estimated average passthroughs and country characteristics. For this reason, we also take a different route by conducting panel estimations of augmented Phillips curves for the whole sample of countries for the period 2001-2010. Whereas this approach obviously imposes constraints, it allows us to study in a richer, dynamic manner how time-varying country characteristics influence the pass-through, while also
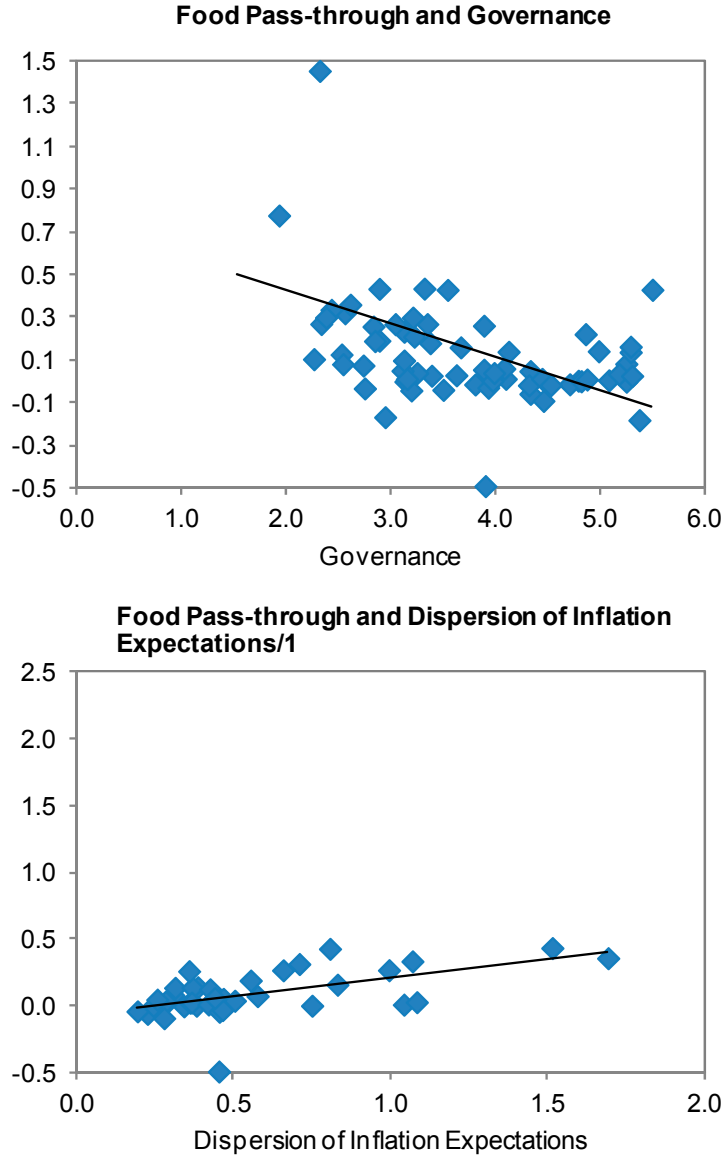

/1 Refers to specifications with commodity price inflation measured in national currencies controlling for cross-country correlations in the error terms.

\footnotetext{
${ }^{15}$ Consensus Forecasts provide data on expectations for 12-month CPI inflation at the end of the current and at the end of the next year. To proxy for 12-month inflation expectations, we construct a weighted average of these two measures, with relative weights dependent on the month of the year (in January, the current end-year forecast is given full weight, in February 11/12, and so forth.)
} 
In addition to the traditional output gap measure, we include in the Phillips curve specification a proxy for marginal costs. ${ }^{16}$ Since a typical firm in a small open economy is likely to use imported intermediate goods in production, we approximate real marginal costs with the deviation of real effective exchange rates (a proxy of the real cost of imported inputs) from a trend. ${ }^{17}$ As argued by Celasun, Gelos, and Prati (2004), the real effective exchange rate is not only a measure of marginal costs, it is closely related to domestic demand pressures: When the real effective exchange rate is above trend, the domestic price level is below the price level of trading partners (adjusted for the long-run trend), and demand pressures will emerge to bring the domestic price level toward foreign prices. ${ }^{18}$

Due to collinearity problems, we limit the interactions included in each regression, and estimate the following specifications:

$$
\begin{aligned}
& \pi_{i, t}=\alpha+\sum_{j=1}^{n} \delta_{j} \pi_{i, t-j}+\sum_{j=0}^{m} \phi_{j} \text { OutputGap }_{i, t-j}+\sum_{j=0}^{p} \omega_{j} R E R \_ \text {dev }_{i, t-j}+ \\
& +\sum_{j=0}^{q} \theta_{j} \pi_{i, t-j}^{\text {WorldFood }}+\sum_{j=0}^{q} \gamma_{j} \pi_{i, t-j}{ }^{\text {WorldFood }} \cdot \text { Country_Char }{ }_{t-j}+\varepsilon_{i, t}
\end{aligned}
$$

and

$$
\begin{aligned}
& \pi_{i, t}=\alpha+\sum_{j=1}^{n} \delta_{j} \pi_{i, t-j}+\sum_{j=0}^{m} \phi_{j} \text { OutputGap }{ }_{i, t-j}+\sum_{j=0}^{p} \omega_{j} R E R \_ \text {dev }_{i, t-j}+ \\
& +\sum_{j=0}^{s} \vartheta_{j} \pi_{i, t-j}^{\text {WorldFuel }}+\sum_{j=0}^{s} \lambda_{j} \pi_{i, t-j}{ }^{\text {WorldFuel }} \cdot \text { Country_Char } r_{i, t-j}+\varepsilon_{i, t}
\end{aligned}
$$

For a subset of countries we also have survey inflation expectations from Consensus Forecasts. We carry out separate estimations for this group of countries, including expected inflation (as measured by the mean of the surveys) in addition to lagged inflation in the estimations. Furthermore, in these cases we also have information on the dispersion (standard deviation) of inflation forecasts. Since this measure can serve as a proxy for inflation uncertainty, we interact it with oil and food price shocks. While the use of survey expectations has become relatively widespread in recent years (see, among others, Fuhrer (2011) and Cerisola and Gelos (2009)), employing information on their dispersion in Phillips curves is not standard and has to our knowledge not yet been carried out in this form.

\footnotetext{
${ }^{16}$ Galí and Gertler (1999) emphasized the role of marginal costs in the Phillips curve.

${ }^{17}$ See Celasun, Gelos, and Prati (2004) and Cerisola and Gelos (2009).

${ }^{18}$ Given the endogeneity of the real effective exchange rate, we instrument it with its own lags and a proxy for foreign demand, the trade-weighted import volume (excluding oil) of industrialized trade partners' imports.
} 


$$
\begin{aligned}
& \pi_{i, t}=\alpha+\beta \cdot E_{t} \pi_{i, t+1}+\sum_{j=1}^{n} \delta_{j} \pi_{i, t-j}+\sum_{j=0}^{m} \phi_{j} \text { OutputGap }_{i . t-j}+\sum_{j=0}^{p} \omega_{j} R E R R_{-} \text {dev }_{i, t-j}+ \\
& +\sum_{j=0}^{q} \theta_{j} \pi_{i, t-j}^{\text {WorldFood }}+\sum_{j=0}^{s} \vartheta_{j} \pi_{i, t-j}{ }^{\text {WorldFuel }}+\varepsilon_{i, t}
\end{aligned}
$$

The estimations were conducted with fixed effects, allowing for heteroskedasticity, serial correlation and cross-country dependence in the error terms, using the Driscoll and Kraay (1998) estimator.

In line with the preceding results, the food and fuel price pass-throughs are larger in more fuel-intensive economies with and those with higher food shares in their CPI baskets. The results from panel estimations also support the notion that governance matters. Inflation targeters seem to have somewhat lower inflation, although the effect is modest. The results also indicate that in an environment of high inflation commodity price shocks have a substantially higher pass-through to domestic inflation. Below we describe our findings in detail (see also Table 1):

- $\quad$ The output gap and the marginal cost measure have the expected signs and enter the regression with significant coefficients. In the specification with inflation expectations, expected inflation enters significantly, but with a low coefficient (possibly because some of the key drivers of expected inflation are included as independent variables).

- $\quad$ Fuel intensity. As expected, the fuel price pass-through is larger in economies that are more fuel-intensive. For example, a sustained increase of 10 percentage points in international fuel price inflation would translate into a 0.4 percentage point increase in inflation in the countries in the top $20^{\text {th }}$ percentile for fuel intensity against 0.01 percentage points in the bottom $20^{\text {th }}$ percentile.

- $\quad$ Food weight in the CPI basket. Similarly, a higher share of food in the CPI is associated with a stronger inflationary impact. A 10 percentage point shock to international food prices, for example, is associated with 1.4 percentage point increase in inflation in the countries in the top $20^{\text {th }}$ percentile for food share in CPI basket against only 0.3 percentage points in the bottom $20^{\text {th }}$ percentile.

- $\quad$ Trade openness. Overall, the effect of higher food and fuel price inflation on domestic inflation is not stronger in more open economies than in more closed ones.

- Exchange-rate stability. Here, again, the evidence is not statistically significant.

- Labor market flexibility. Indices of labor market flexibility are not significantly correlated with the inflation impact.

- $\quad$ High inflation environment. The impact of commodity price fluctuations is substantially larger when inflation already exceeds 10 percent. In countries where inflation exceeds that threshold, the impact of a 10 percentage point rise in food inflation translates on average into a 1 percentage point higher CPI inflation than in countries with lower initial inflation rates. 
- Inflation targeting. The estimates reveal a statistically significant, but minor effect of the presence of IT regimes on the inflationary impact of commodity price shock. A 10 percentage point increase in international fuel price inflation, for example, is associated with only a 0.2 percentage point lower long-term inflationary impact for inflation targeters. The effect of inflation targeting survives the inclusion of indices of central bank autonomy and governance.

- $\quad$ Central Bank autonomy. In line with a priori expectations, the sign of the sum of interaction coefficients is negative, with higher indices of central bank autonomy associated with a lower inflationary impact. However, the effect is not statistically significant.

- Governance. Countries with better governance frameworks seem to find it easier to contain the inflationary impact of food price shocks. This result holds even when controlling for the presence of IT regimes. For example, in response to an increase in food inflation by 10 percentage points, a country at the bottom $20^{\text {th }}$ percentile in the governance rating will experience a 0.9 percentage point higher increase in inflation than a country in the top $20^{\text {th }}$ percentile.

- Dispersion of inflation expectations. The effect is ambiguous and not statistically significant. In line with a priori expectations, a higher dispersion of inflation expectations is associated with a bigger inflationary impact of international food price shocks, but the reverse is true for fuel (although the magnitude of the effect is very small in the latter case).

- $\quad$ Financial development. A higher degree of financial development (as measured by a larger M3-to-GDP ratio) is associated with a slightly larger impact of commodity price shocks, contrary to what one may expect (not shown).

- $\quad$ Public debt. Higher public debt levels are negatively associated with the size of transmission of external commodity shocks to domestic inflation (not shown). The coefficients are significant in both specifications with food and fuel price interaction terms. This counterintuitive result could stem from an omitted variable bias.

- Importers dummy. The coefficients for the interaction terms with fuel and food prices are not significant (not shown).

- $\quad$ Financial development. The ratio of broad money over GDP is not statistically significantly associated with the inflationary impact of commodity prices. 
Table 1. Phillips Curves - Panel Estimations

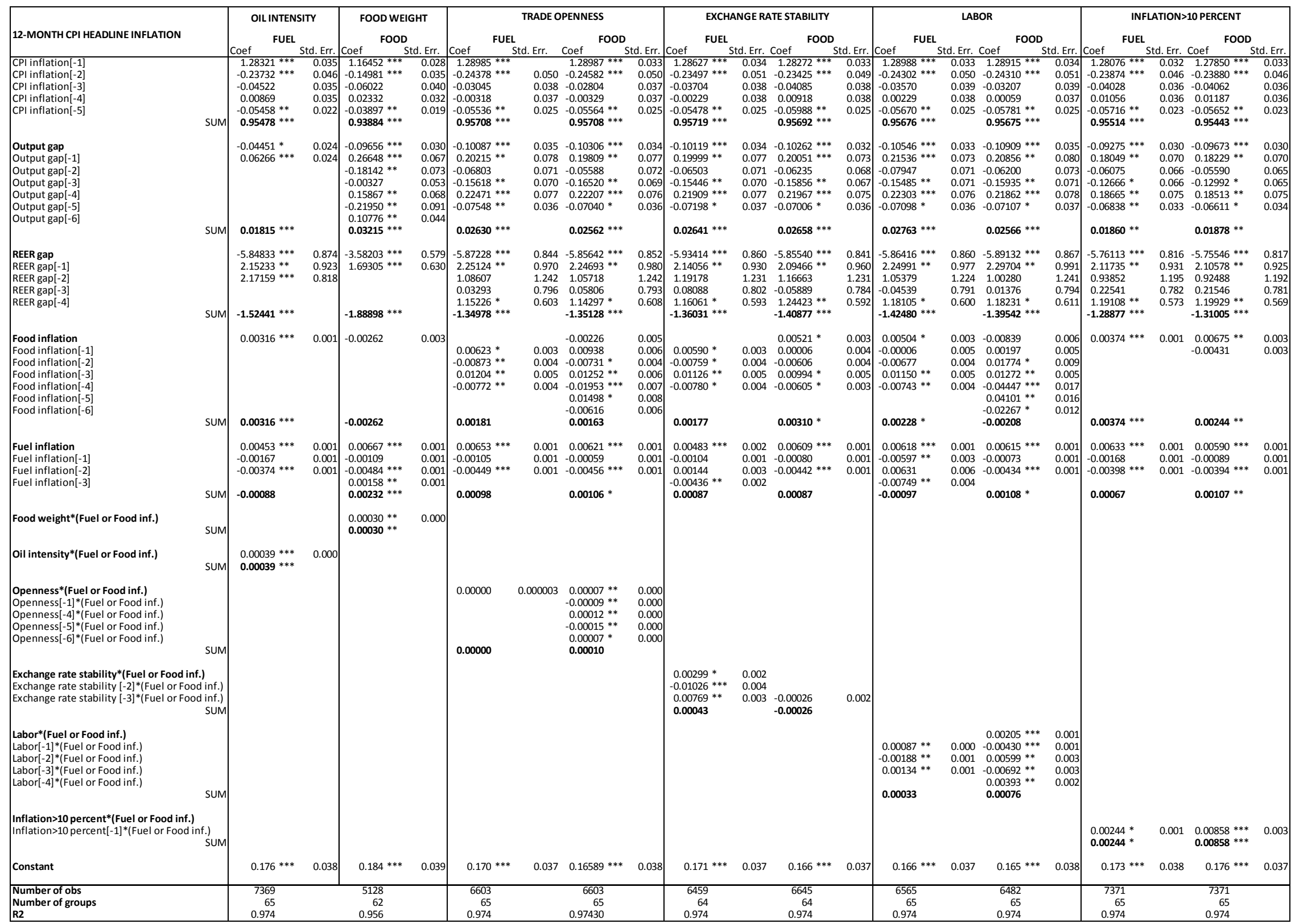




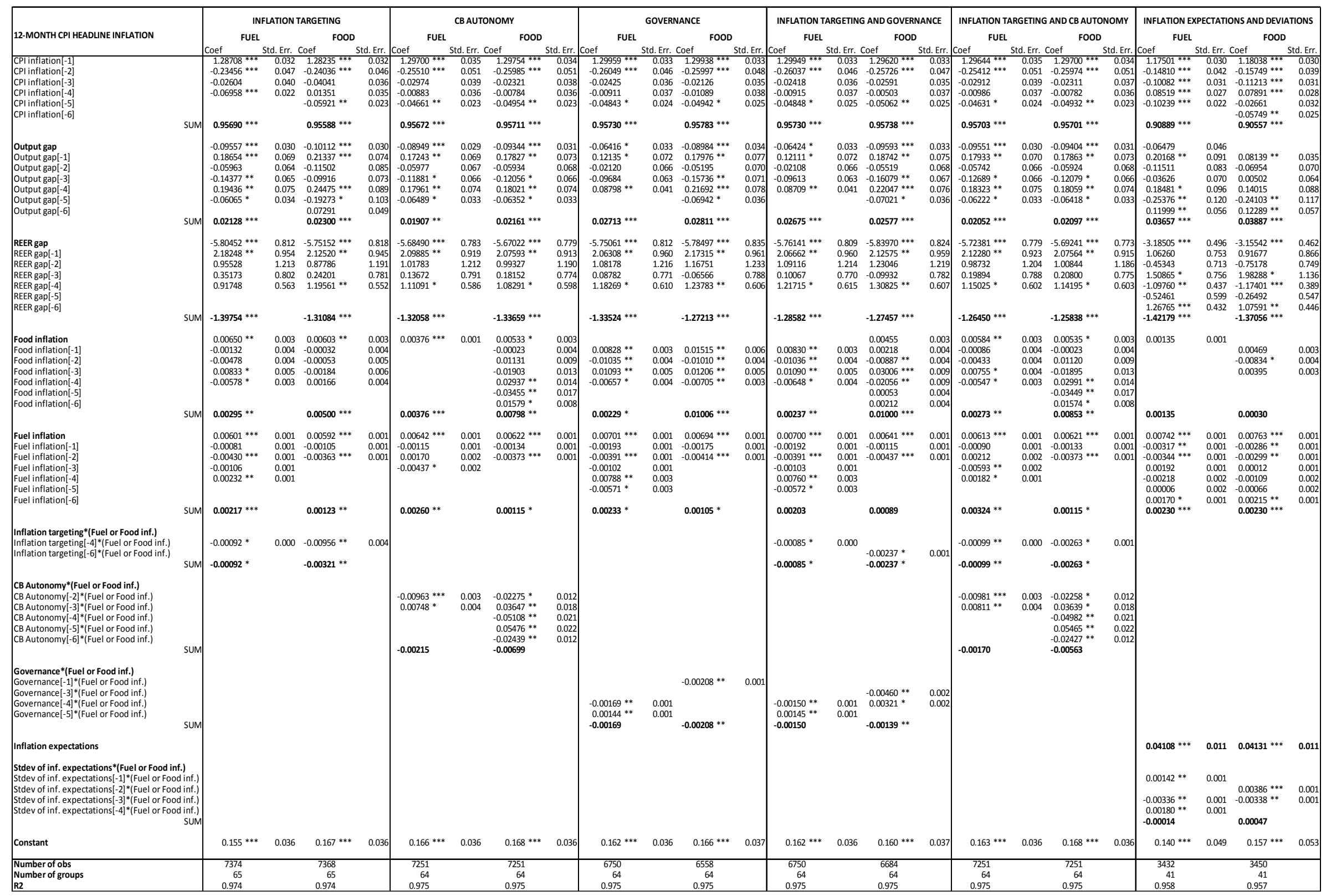




\section{The 2008 Commodity-Price Shock}

While the analysis so far has covered longer time periods, the dynamics of economic variables may be different around the large shocks. Moreover, pass-through estimations may suffer from various problems, including measurement issues and difficulties in specifying adequate Phillips curves for developing countries in the presence of recurrent structural breaks. These problems are less severe when focusing on an 'event study' surrounding a large shock. Therefore, we examine the 2008 commodity-price shock episode in more detail, to assess how countries coped with this large increase in international prices. We compute both the changes in headline and core inflation six months before and after the peak of international food and fuel price inflation in March 2008, and explore the extent to

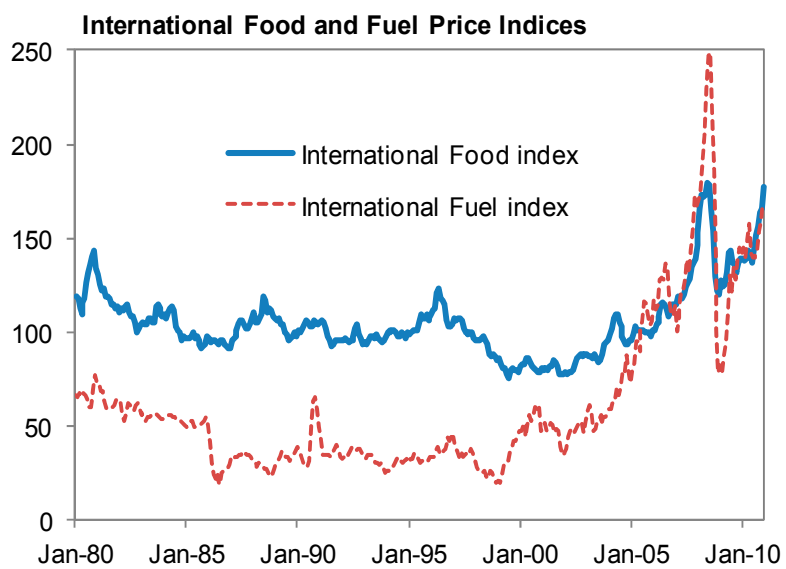
which they are related to the country-level variables discussed earlier. ${ }^{19}$

\section{Changes in headline inflation}

As expected, countries with higher food shares in their CPI baskets confronted stronger inflationary pressures (Table 2). However, variables proxying for the importance of fuel in the economy and the CPI were not consistently correlated with the inflationary impact. On the other hand, the energy intensity of the economies in the sample is positively associated with the experienced increase in headline inflation, at least in some specifications. Similarly, to some extent, the inflationary impact was weaker for fuel importers, as expected. ${ }^{20} \mathrm{We}$ are not able to capture any significant effect of demand conditions; the output gap does not enter significantly in any of the regressions. We did not find any correlation with our measure of labor market flexibility, either.

The pre-existing inflation environment was key in determining the impact of the international commodity price shock on domestic prices: in line with Taylor's (2000) argument and the findings from the panel regressions, countries with higher initial inflation levels experienced a much more marked increase in CPI inflation. The effect is sizeable: a country that had a

\footnotetext{
${ }^{19}$ Habermeier et al (2009) examine some pairwise correlations of country characteristics and policy variables, with the accumulated headline inflation from Dec 2006 through June 2008. Similarly, Pistelli and Riquelme (2010) analyze the impact of the commodity price boom-and-bust cycle during 2007 and 2008 with a sample of 44 countries focusing on a few structural variables.

${ }^{20}$ The same was not true for food importers.
} 
headline inflation of, say, 3 percent in early 2007 saw on average a $1.5-2.5$ percentage point lower rise in inflation than a country with an initial inflation of 8 percent.

Countries with more autonomous central banks saw a weaker increase in CPI inflation around the commodity price shock. However, interestingly, there is no statistically significant difference between the performances of inflation targeting versus non-inflation targeting economies.

Not surprisingly, the policy reaction around the shock also mattered: countries with a tighter monetary stance - as measured by their real short-term interest rates and the change in the nominal effective exchange rate- experienced lower hikes in inflation rates. This was also the case for economies where fiscal policy was tighter. ${ }^{21}$

The dispersion of Consensus Forecasts survey projections for inflation in 2008 (measured as the standard deviation across forecasters at end-2007) estimates is positively correlated with inflation outcomes, but this is driven mainly by two outliers.

\section{Changes in core inflation}

A possibly more relevant issue is to understand differences in the transmission of commodity price shocks to core inflation. As discussed earlier, more credible monetary frameworks should help contain food and fuel price spillovers to core inflation.

Here, the impact was clearly lower in developing countries with more autonomous central banks, and to some extent in countries with better governance structures (Table 3). The effect is economically significant: raising the degree of autonomy from the bottom to the top fifth percentile of the index distribution would on average be associated with a 3.5 percentage point lower increase in core inflation. However, again there is no evidence of a stronger performance of inflation targeters.

Similarly as in the case of headline inflation, the food share in the CPI is positively correlated with the impact on core inflation. However, this is not the case for proxies of the role of fuel.

The transmission to core inflation was stronger for countries with higher CPI inflation levels. Policy variables do not enter significantly the regressions, except for the degree of exchange rate movements, with appreciations of the nominal effective exchange rate associated with a lower impact on core inflation.

\footnotetext{
${ }^{21}$ Neither the change in real interest rates nor the fiscal impulse (measured as the change in the structural fiscal balance) was statistically significantly associated with inflation outcomes. The growth in money aggregates did not enter the regressions in a consistently statistically significant manner, either.
} 


\section{TABLE 2. CHANGE IN HEADLINE INFLATION AROUND 2008 SHOCK}

Dependent Variable: Change in 12-month CPI headline inflation between September 2007 and September 2008

\begin{tabular}{|c|c|c|c|c|c|c|c|c|c|c|}
\hline & (1) & (2) & (3) & (4) & (5) & (6) & (7) & (8) & (9) & (10) \\
\hline & & & & & & & \multicolumn{3}{|c|}{ Including Policy Variables } & \\
\hline Food Weight in CPI & $\begin{array}{l}0.0013 \text { ** } \\
(0.0004)\end{array}$ & $\begin{array}{l}0.00111^{* *} \\
(0.0004)\end{array}$ & $\begin{array}{l}0.0009 * * \\
(0.001)\end{array}$ & $\begin{array}{l}0.0007 * \\
(0.000)\end{array}$ & $\begin{array}{r}0.0005 \\
(0.0004)\end{array}$ & & & & & $\begin{array}{l}0.0009 * * \\
(0.0004)\end{array}$ \\
\hline $\begin{array}{l}\text { Fuel Importer } \\
\text { Dummy }\end{array}$ & & $\begin{array}{l}-0.029^{* *} \\
(0.012)\end{array}$ & $\begin{array}{l}-0.026^{* *} \\
(0.012)\end{array}$ & $\begin{array}{c}-0.02 * \\
(0.011)\end{array}$ & $\begin{array}{r}-0.014 \\
(0.011)\end{array}$ & & & & & \\
\hline IT Dummy & & & $\begin{array}{r}-0.012 \\
(0.011)\end{array}$ & & & & & & & \\
\hline Lagged Inflation & & & & $\begin{array}{l}0.5^{* * *} \\
(0.130)\end{array}$ & $\begin{array}{l}0.48^{* *} \\
(0.130)\end{array}$ & & $\begin{array}{l}0.39 * * * \\
(0.120)\end{array}$ & $\begin{array}{l}0.311^{* *} \\
(0.140)\end{array}$ & $\begin{array}{l}0.36^{* * *} \\
(0.110)\end{array}$ & $\begin{array}{l}0.49^{* * *} \\
(0.100)\end{array}$ \\
\hline CB Autonomy/1 & & & & & $\begin{array}{l}-0.06 * * \\
(0.03)\end{array}$ & $\begin{array}{l}-0.04 * \\
(0.02)\end{array}$ & $\begin{array}{l}-0.06 * * \\
(0.030)\end{array}$ & $\begin{array}{r}-0.04 \\
(0.030)\end{array}$ & $\begin{array}{r}-0.04 \\
(0.023)\end{array}$ & \\
\hline Energy Intensity & & & & & & $\begin{array}{l}0.33^{* *} \\
(0.14)\end{array}$ & $\begin{array}{r}0.2 \\
(0.150)\end{array}$ & $\begin{array}{c}0.33 * \\
(0.180)\end{array}$ & $\begin{array}{r}0.21 \\
(0.140)\end{array}$ & \\
\hline Governance & & & & & & $\begin{array}{r}-0.004 \\
(0.005)\end{array}$ & & & & \\
\hline ST Real Interest Rate & & & & & & & $\begin{array}{l}-0.002 * * \\
(0.001)\end{array}$ & $\begin{array}{l}-0.003 * * * \\
(0.001)\end{array}$ & $\begin{array}{l}-0.003 * * \\
(0.001)\end{array}$ & \\
\hline $\begin{array}{l}2007 \text { Fiscal Structural } \\
\text { Balance }\end{array}$ & & & & & & & & $\begin{array}{l}-0.003 * \\
(0.002)\end{array}$ & & \\
\hline Change in NEER/2 & & & & & & & & & $\begin{array}{l}-0.18^{* * *} \\
(0.060)\end{array}$ & $\begin{array}{l}-0.18 * * * \\
(0.060)\end{array}$ \\
\hline Obs. & 66 & 66 & 66 & 66 & 65 & 77 & 63 & 45 & 63 & 65 \\
\hline R-squared & 0.12 & 0.2 & 0.21 & 0.35 & 0.37 & 0.4 & 0.42 & 0.55 & 0.51 & 0.4 \\
\hline
\end{tabular}

Standard errors in parentheses. ${ }^{* * *}$ denotes $\mathrm{p}$-value $<0.01, * *$ denotes $\mathrm{p}$-value $<0.05, *$ denotes $\mathrm{p}$-value $<0.10$

/1 Orthogonalized component to central bank autonomy when the latter variable is included in the regression.

$/ 2$ Increase implies appreciation 


\section{TABLE 3. ChANGE in CORE INFLATION AROUND 2008 SHOCK}

Dependent Variable: Change in 12-month CPI core inflation between September 2007 and September 2008

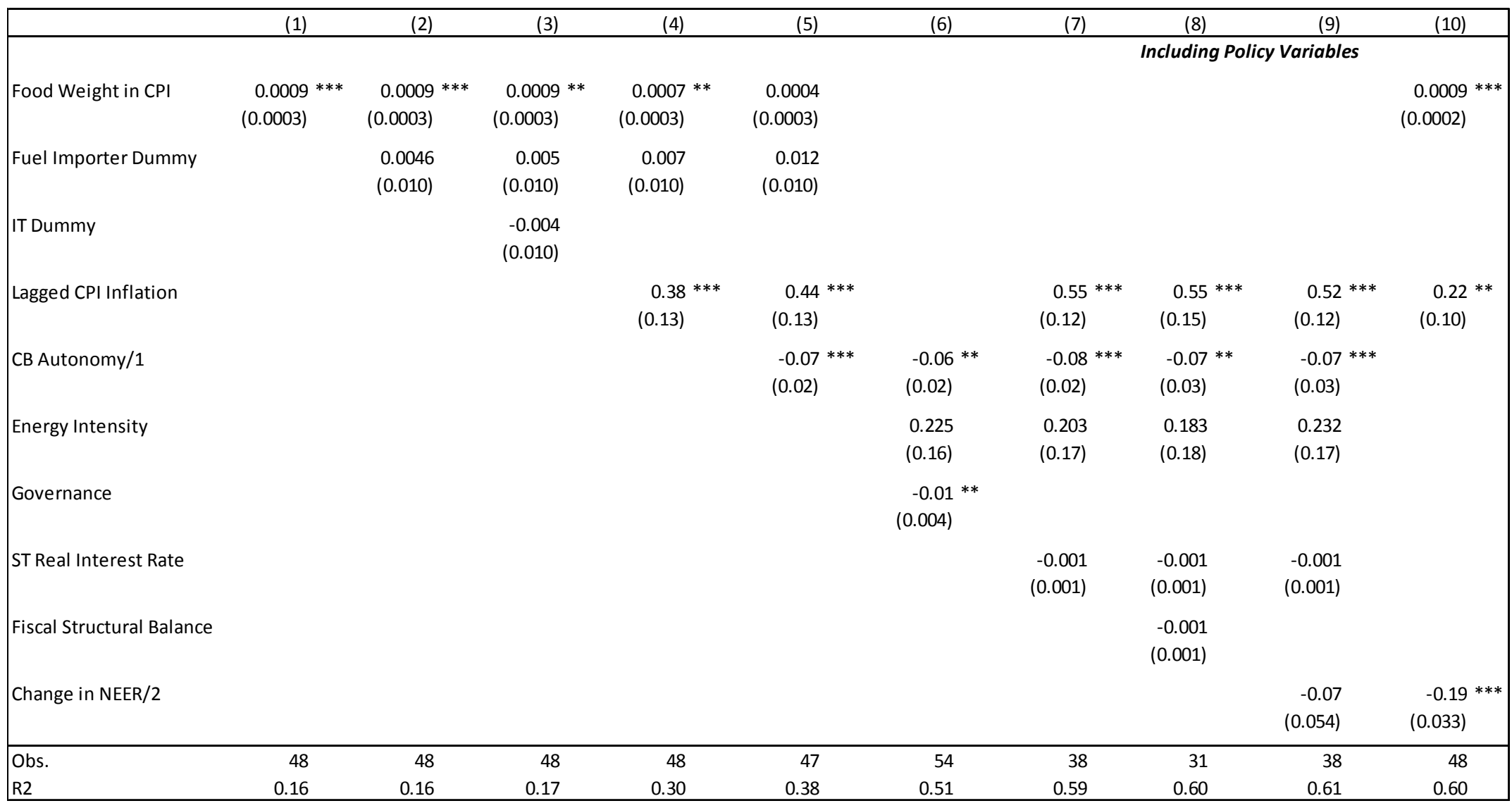

Standard errors in parentheses. ${ }^{* * *}$ denotes p-value $<0.01,{ }^{* *}$ denotes p-value $<0.05, *$ denotes p-value $<0.10$

/1 Orthogonalized component to central bank autonomy when the latter variable is included in the regression.

$/ 2$ Increase implies appreciation. 


\section{Change in Headline Inflation around March 2008 and Energy Intensity}
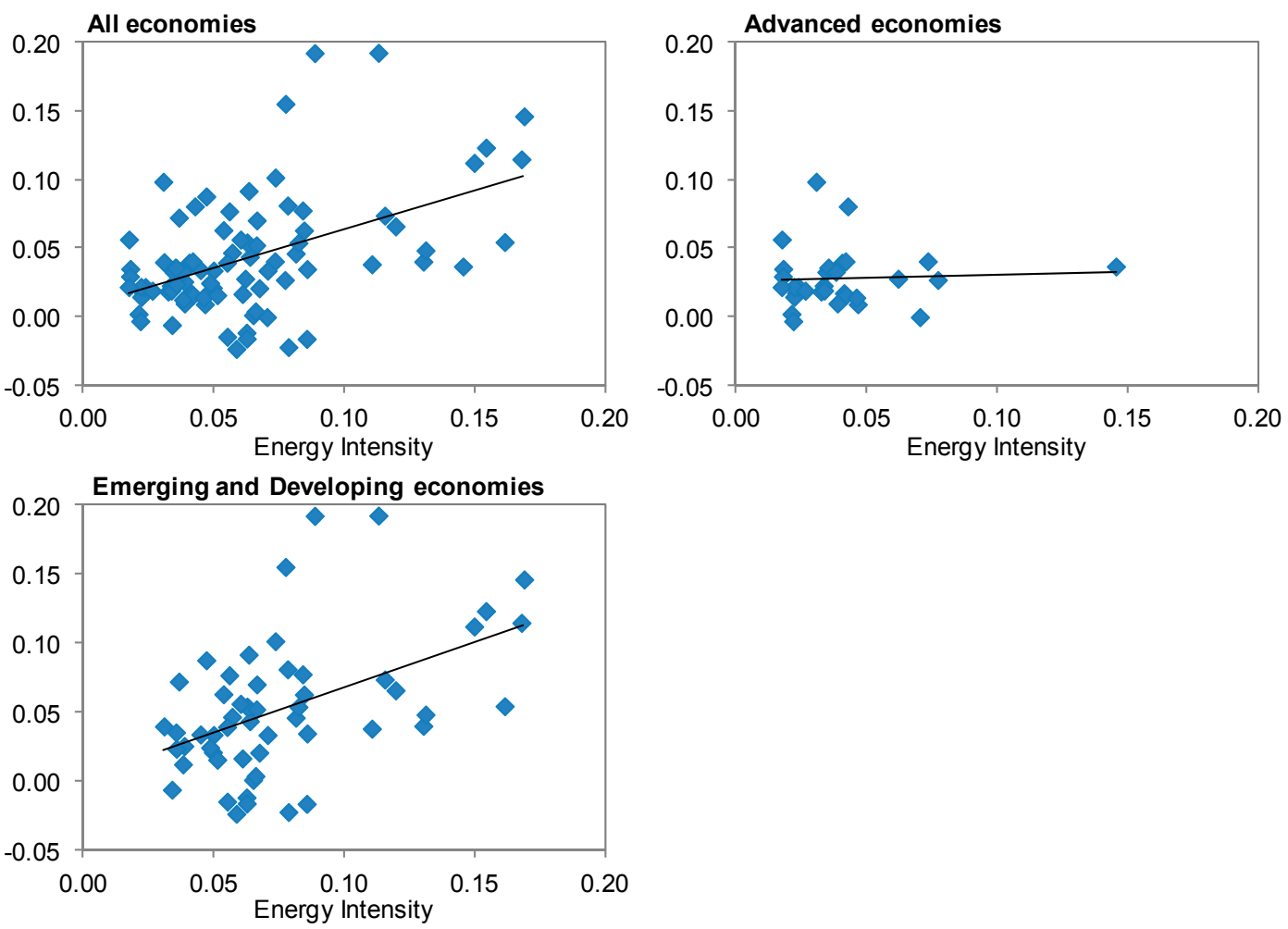

\section{Change in Headline Inflation around March 2008 and Food Weight in CPI Basket}
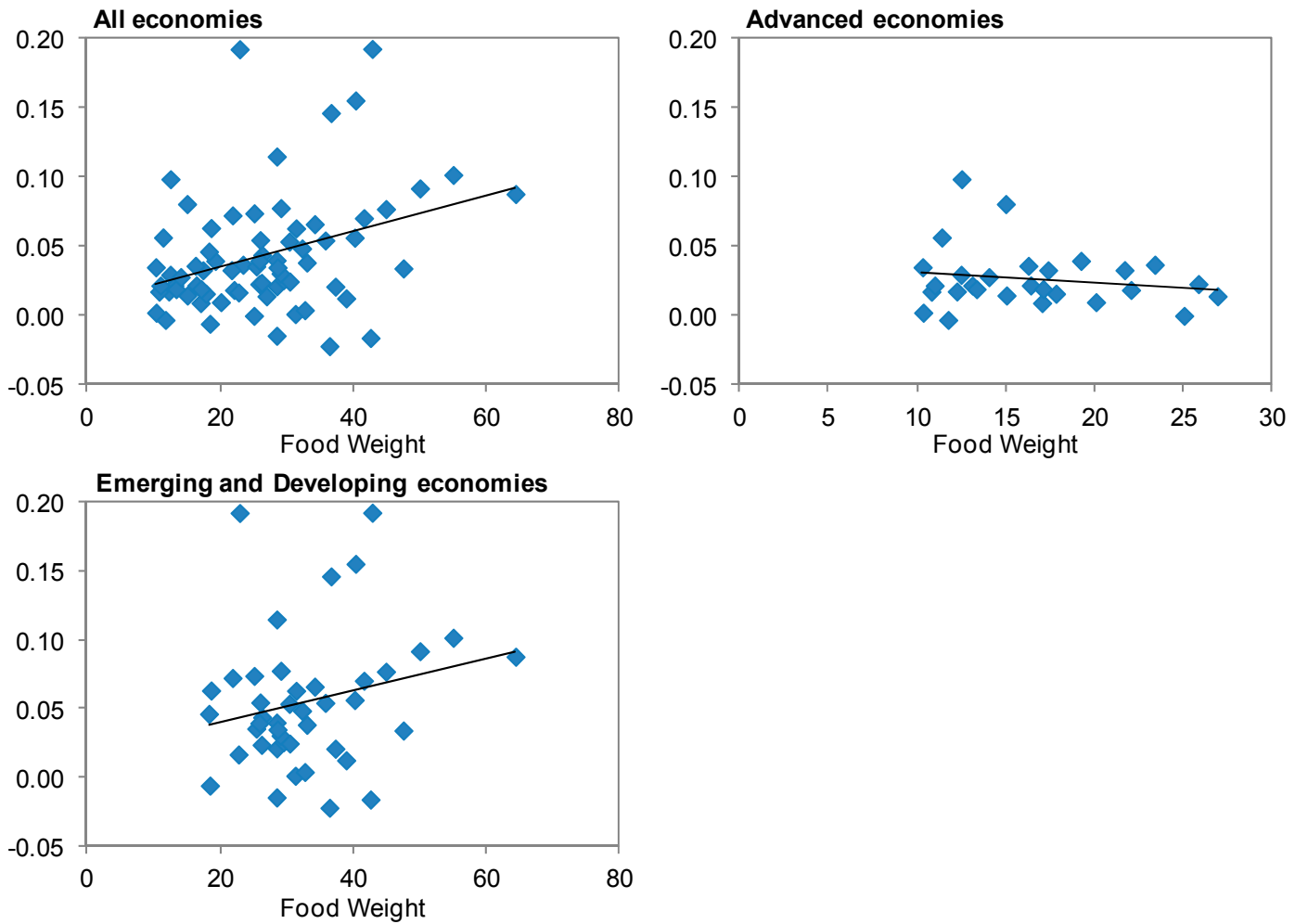
Change in Headline Inflation around March 2008 and IT Dummy
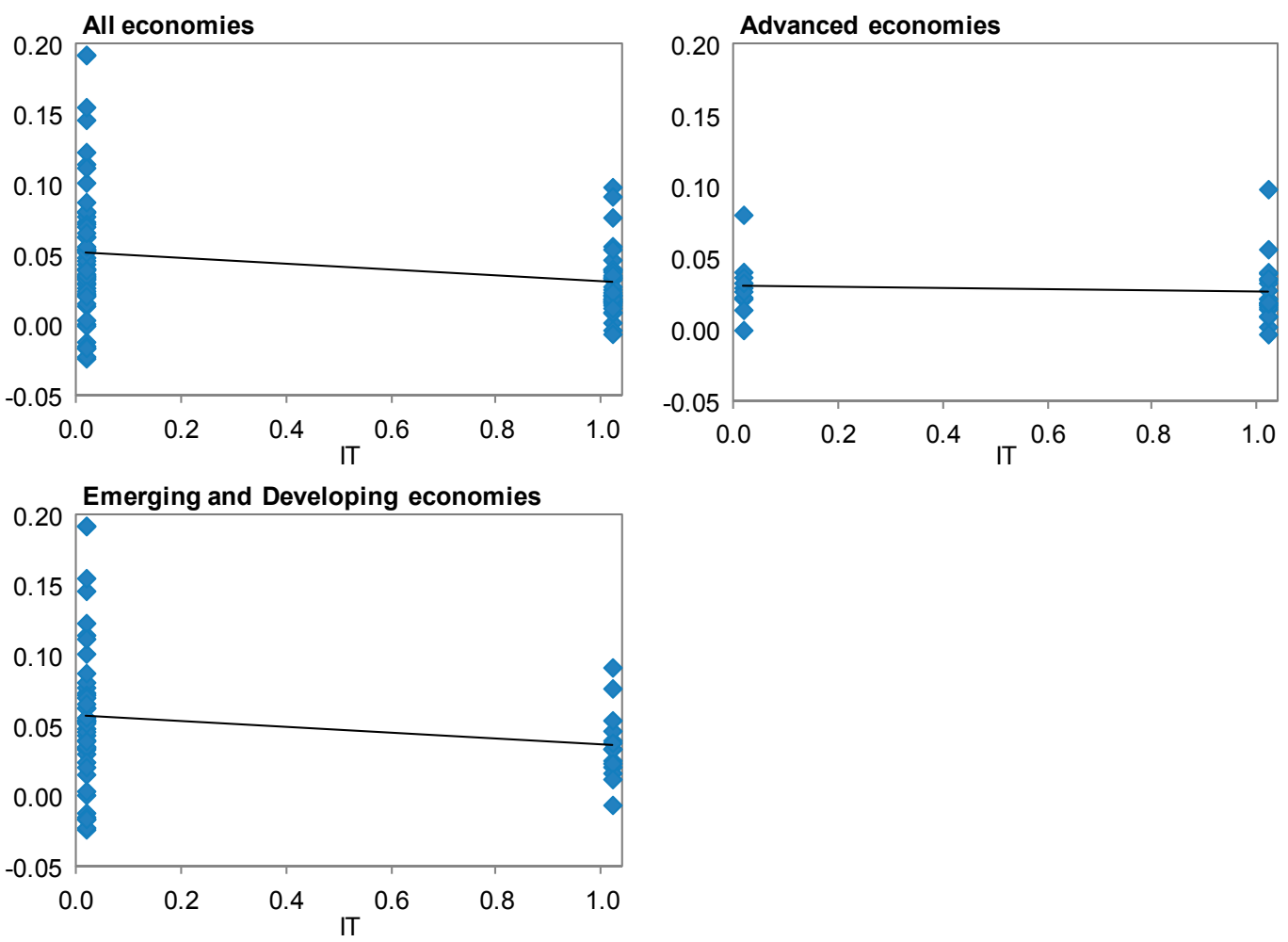

Change in Headline Inflation around March 2008 and Central Bank Autonomy
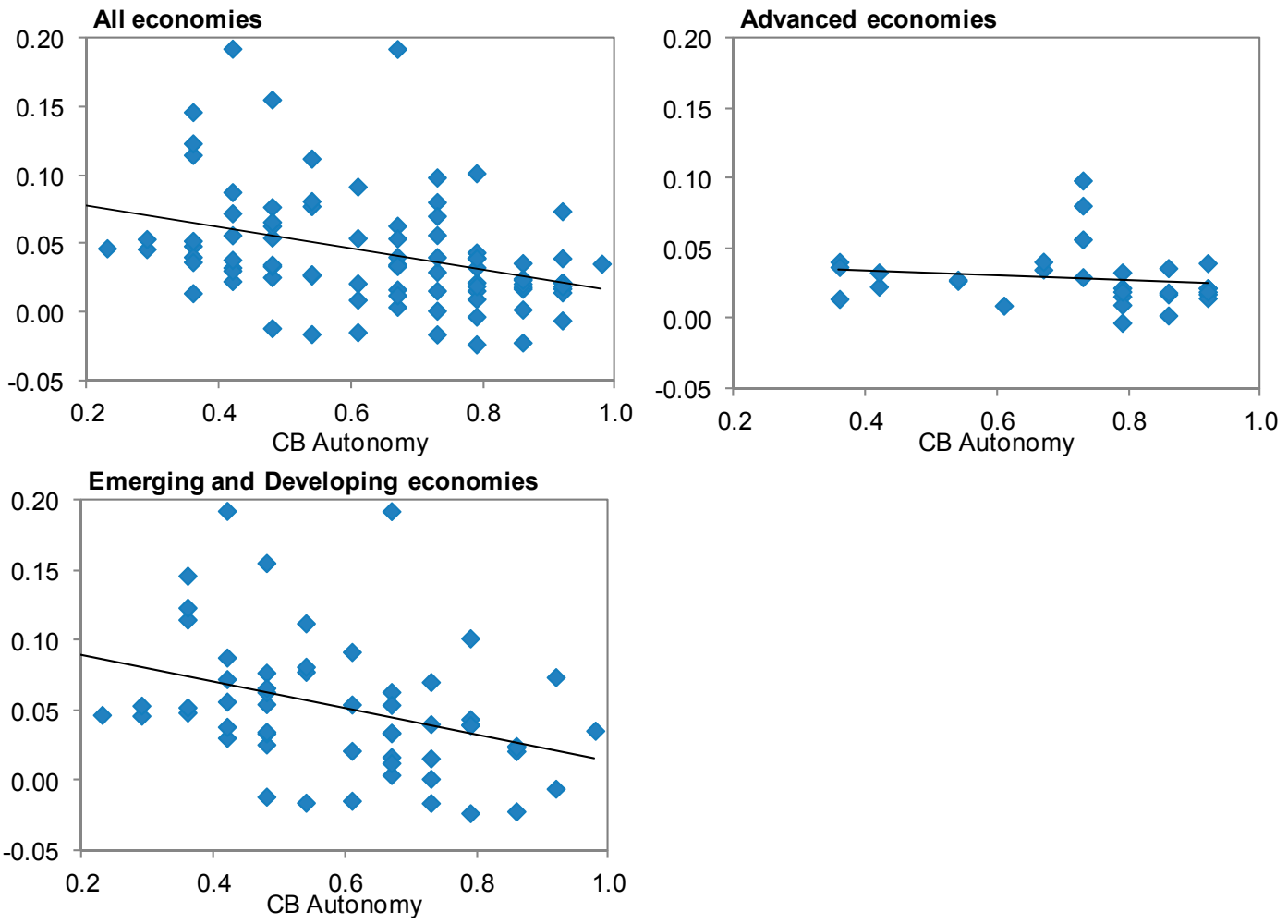


\section{Conclusions}

This study has carried out an extensive assessment of the effects of international commodity price shocks on domestic inflation across a wide range of countries, using a variety of methods. A few lessons can be drawn:

- $\quad$ Countries with certain structural characteristics are more prone to experience sustained inflationary effects from commodity price shocks. These characteristics include a high weight of food in the CPI basket and a high oil intensity of the economy. Around the 2008 shock, net fuel importers also faced somewhat lower inflationary pressures, in line with terms of trade effects.

- $\quad$ Countries can, however, influence the degree to which domestic inflation reacts to international commodity price movements: better overall governance, greater central bank autonomy, and, to a lesser extent, the adoption of inflation targeting frameworks seem to help anchor inflation expectations and reduce second-round effects.

However, the evidence suggests that the overall confidence in institutions may be more important than whether a country declares itself formally as an inflation targeter or not.

- $\quad$ Policy actions also matter: around the 2008 commodity shock, tighter monetary policy (as measured by the real interest rate) helped contain the inflationary impact. To a lesser degree, this is also true for tight fiscal policy.

- If inflation is already relatively high to begin with, commodity price shocks have a substantially higher pass-through to domestic inflation.

Further research could examine more systematically the formation of inflation expectations around commodity price shocks and their influence in shaping inflation dynamics; more work using microeconomic information on price movements around such shocks could also lead useful insights. 


\section{REFERENCES}

Arnone, Marco; Laurens, Bernard; Segalotto, Jean-François; Sommer, Martin, 2007, "Central Bank Autonomy: Lessons from Global Trends," IMF Working Paper 07/88 (Washington: International Monetary Fund).

Bailliu, Jeannine and Eiji Fujii, 2004, "Exchange Rate Pass-Through and the Inflation Environment in Industrialized Countries: An Empirical Investigation,” Bank of Canada, Working Paper 2004-21.

Baumeister, C., G. Peersman and I. Van Robays (2010), 'The economic consequences of oilshocks: Differences across countries and time', in R. Fry, C. Jones and C. Kent (eds), Inflation in an Era of Relative Price Shocks, Reserve Bank of Australia, 91-128.

Blanchard, Olivier, and Jordí Galí, 2007, "The Macroeconomic Effects of Oil Price Shocks: Why are the 2000s so Different from the 1970s?", NBER Working Paper No. 13368.

Borio, Claudio and Andrew Filardo, 2007, "Globalisation and inflation: New cross-country evidence on the global determinants of domestic inflation," BIS Working Paper No. 227, Bank for International Settlements.

Brito, Ricardo D. and Brianne Bystedt, 2010, "Inflation Targeting in Emerging Economies: Panel Evidence," Journal of Development Economics 91, pp. 198-210.

Burstein, Ariel, Eichenbaum, Martin, Rebelo, Sergio, 2007. "Modeling exchange rate passthrough after large devaluations," Journal of Monetary Economics, Elsevier, Vol. 54(2), pages 346-368, March.

Catao, Luis, and Roberto Chang, 2010, "World Food Prices and Monetary Policy," NBER Working Paper 16563.

Cecchetti, Stephen C. and Richhild Moessner, 2008, "Commodity Prices and Inflation Dynamics," BIS Working Paper.

Celasun, Oya, Gaston Gelos, and Alessandro Prati, 2004, "Obstacles to Disinflation: What is the Role of Fiscal Expectations?," Economic Policy, October 2004.

Cerisola, Martin and Gaston Gelos, 2009, "What Drives Inflation Expectations in Brazil? An Empirical Analysis," Applied Economics, May 2009.

Chen, Shiu-Sheng, 2009, “Oil Price Pass-Through into Inflation,” Energy Economics, Vol. 31, pp. 126-33.

Clark, T (2001): “Comparing measures of core inflation", Federal Reserve Bank of Kansas City Economic Review, Vol. 86, No 2, pp 5-31. 
De Gregorio, José, Oscar Landerretche, and Christopher Neilson, 2007, "Another PassThrough Bites the Dust? Oil Prices and Inflation," Economía, Vol. 7, No. 2, pp. 155-208.

Driscoll, J. C. and A. C. Kraay, 1998, "Consistent Covariance Matrix Estimation with Spatially Dependent Panel Data," Review of Economics and Statistics 80, pp. 549-60.

Fuhrer, Jeffrey, 2011, “The Role of Expectations in U.S. Inflation Dynamics,” Federal Reserve Bank of Boston, Working Paper 11-11.

Gwartney, James, Robert Lawson, and Seth Norton, 2010, "Economic Freedom of the World: 2008 Annual Report," Vancouver, BC: The Fraser Institute.

Habermeier, Karl, Inci Ötker-Robe, Luis Jacome, Alessandrom Giustiniani, Kotaro Ishi, David Vavra, Turgut Kişinbay, and Francisco Vázquez, 2009, "Inflation Pressures and Monetary Policy Options in Emerging and Developing Countries: A Cross Regional Perspective," IMF Working Paper 09/01 (Washington: International Monetary Fund).

Hakura, Dalia, 2005, “Are Emerging Market Countries Learning to Float?,” IMF Working Paper (Washington: International Monetary Fund).

Hooker, Mark, 2002, “Are Oil Shocks Inflationary? Asymmetric and Nonlinear Specifications versus Changes in Regime," Journal of Money, Credit, and Banking, 34 (2), 540-61.

International Monetary Fund, 2008, "World Economic Outlook," October (Washington: International Monetary Fund).

, 2011, "World Economic Outlook," October (Washington: International Monetary Fund).

Kim, M., Beladi, H.,2005, “Is free trade deflationary?.” Economics Letters, 89, pp. 343-349.

Levy Yeyati, Eduardo, "Financial Dollarization: Evaluating the Consequences," Economic Policy, January 2006, pp. 61-118.

Lora, Eduardo, Andrew Powell, and Pilar Tavella, 2010, "How Will the Food Price Shock Affect Inflation in Latin America and the Caribbean?," IDB Policy Brief IDB-PB120.

Neely, Christopher J. and David E. Rapach, 2011, "International Comovements in Inflation Rates and Country Characteristics," Journal of International Money and Finance, 30, pp. 1471-1490.

Pain, Nigel, Koske, Isabell, Sollie, Marte, 2006, "Globalisation and Inflation in the OECD Economies," Working Paper, Economics Department, OECD. 
Pedersen, M. (2010), "Propagation of inflationary shocks in Chile and an international comparison of propagation of shocks to food and energy prices", Working Paper No. 566, Central Bank of Chile.

Pistelli, A. and V. Riquelme (2010), “Auge y caída de precios de commodities y su impacto sobre precios domésticos: Comparación internacional”, Working Paper No. 567, Central Bank of Chile.

Rigobon, R., 2010, “Commodity prices pass-through”, Working Paper No. 572, Central Bank of Chile.

Romer, D., 1993, “Openness and inflation: theory and evidence," Quarterly Journal of Economics, 58, 869-903.

Roger, Scott, 2009, "Inflation Targeting at 20: Achievements and Challenges," IMF Working Paper 09/236 (Washington: International Monetary Fund).

Rogoff, Kenneth, Husain, Aasim M., Mody, Ashoka, Brooks, Robin, and Oomes, Nienke, 2004, "Evolution and Performance of Exchange-Rate Regimes," Occasional Paper No. 229, International Monetary Fund (Washington: International Monetary Fund).

Saizar, Ana Carolina, Chalk, Nigel, 2008, "Is Monetary Policy Effective When Credit is Low?”, IMF Working Paper 08/288 (Washington: International Monetary Fund).

So Im, Kyung, Lee, Junsoo, Tieslau Margie, 2010 "Stationarity of Inflation: Evidence from Panel Unit Root Tests with Trend Shifts" 20th Annual Meetings of the Midwest Econometrics Group, Oct 1-2, 2010

Taylor, John, 2000, "Low Inflation, Pass-Through, and the Pricing Power of Firms," European Economic Review, 44 (7), pp. 1389-408.

Terra, C., 1998,“Openness and inflation: a new assessment,“ Quarterly Journal of Economics, 63, 641-648.

Walsh, James P., 2011, "Reconsidering the Role of Food Prices in Inflation," IMF Working Paper 11/71 (Washington: International Monetary Fund).

Zoli, Edda, 2009, "Commodity Price Volatility, Cyclical Fluctuations, and Convergence: What is Ahead for Inflation in Emerging Europe?," IMF Working Paper 09/41 (Washington: International Monetary Fund). 
Appendix I. List of Countries Included

Advanced economies
Austria
Belgium
Canada
Cyprus
Czech Republic
Denmark
Estonia
Finland
France
Germany
Greece
Hong Kong
Iceland
Ireland
Israel
Italy
Japan
Korea, South
Malta
Netherlands
New Zealand
Norway
Portugal
Singapore
Slovenia
Spain
Sweden
Switzerland
Taiwan
UK
USA

Emerging and Developing Economies

\begin{tabular}{|c|c|}
\hline Albania & Lithuania \\
\hline Algeria & Macao \\
\hline Argentina & Macedonia \\
\hline Bahrain & Malaysia \\
\hline Bangladesh & Mauritius \\
\hline Bolivia & Mexico \\
\hline Botswana & Namibia \\
\hline Brazil & Nicaragua \\
\hline Bulgaria & Nigeria \\
\hline Chile & Oman \\
\hline China & Pakistan \\
\hline Colombia & Panama \\
\hline Costa Rica & Paraguay \\
\hline Croatia & Peru \\
\hline Dominican Republic & Philippines \\
\hline Ecuador & Poland \\
\hline Egypt & Romania \\
\hline El Salvador & Russia \\
\hline Georgia & Saudi Arabia \\
\hline Ghana & South Africa \\
\hline Guatemala & Sri Lanka \\
\hline Honduras & Thailand \\
\hline Hungary & Tunisia \\
\hline India & Turkey \\
\hline Indonesia & Uganda \\
\hline Iran & Ukraine \\
\hline Jordan & United Arab Emirates \\
\hline Kazakhstan & Uruguay \\
\hline Kuwait & Venezuela \\
\hline Latvia & Vietnam \\
\hline
\end{tabular}




\section{Appendix II. Data Sources}

\begin{tabular}{|c|c|c|c|}
\hline Variable & Units & Description & Source \\
\hline Headline inflation & Percent & CPI inflation & $\begin{array}{l}\text { Haver Analytics and WEO } \\
\text { database }\end{array}$ \\
\hline Core inflation & Percent & Core CPI inflation & $\begin{array}{l}\text { Haver Analytics and WEO } \\
\text { database }\end{array}$ \\
\hline Global food inflation & Percent & $\begin{array}{l}\text { Yearly change in the index of } \\
\text { food prices }\end{array}$ & WEO database \\
\hline Global fuel inflation & Percent & $\begin{array}{l}\text { Yearly change in the index of } \\
\text { fuel prices }\end{array}$ & WEO database \\
\hline Output gap & Percent & Based on HP filter & $\begin{array}{l}\text { WEO database, staff } \\
\text { calculations }\end{array}$ \\
\hline REER Gap & Percent & $\begin{array}{l}\text { REER deviation from trend, } \\
\text { based on HP filter }\end{array}$ & IMF, staff calculations \\
\hline Inflation expectations & Percent & Survey inflation expectations & $\begin{array}{l}\text { Consensus Forecasts, staff } \\
\text { calculations }\end{array}$ \\
\hline $\begin{array}{l}\text { Dispersion of } \\
\text { inflation expectations }\end{array}$ & Percent & $\begin{array}{l}\text { Standard deviation of survey } \\
\text { inflation expectations }\end{array}$ & $\begin{array}{l}\text { Consensus Forecasts, staff } \\
\text { calculations }\end{array}$ \\
\hline \multicolumn{4}{|c|}{ Structural characteristics of the economy } \\
\hline Trade openness & Percent & $\begin{array}{l}\text { Calculated as sum of exports and } \\
\text { imports divided by GDP }\end{array}$ & $\begin{array}{l}\text { Haver Analytics and WEO } \\
\text { database }\end{array}$ \\
\hline Food share in CPI & Percent & $\begin{array}{l}\text { Share of food items in CPI } \\
\text { baskets }\end{array}$ & $\begin{array}{l}\text { Haver Analytics and WEO } \\
\text { database }\end{array}$ \\
\hline Fuel Intensity & Percent & $\begin{array}{l}\text { Calculated as annual oil } \\
\text { consumption divided by GDP }\end{array}$ & EIA, staff calsulations \\
\hline $\begin{array}{l}\text { Degree of financial } \\
\text { dollarization }\end{array}$ & Percent & $\begin{array}{l}\text { Foreign exchange deposits over } \\
\text { total deposits }\end{array}$ & $\begin{array}{l}\text { Levy Yeyati (2006) (with } \\
2010 \text { database update) and } \\
\text { IFS }\end{array}$ \\
\hline $\begin{array}{l}\text { Financial } \\
\text { development }\end{array}$ & Percent & Broad money as a share of GDP & IFS, staff calculations \\
\hline Fiscal dominance & Percent & $\begin{array}{l}\text { General government public debt } \\
\text { in percent of GDP }\end{array}$ & IMF \\
\hline \multicolumn{4}{|c|}{ Monetary and exchange-rate regimes } \\
\hline $\begin{array}{l}\text { Inflation Targeting } \\
\text { regime }\end{array}$ & Dummy & $\begin{array}{l}1 \text { if the country's monetary } \\
\text { policy framework is inflation } \\
\text { targeting }\end{array}$ & Roger (2009) \\
\hline CB autonomy index & Index number & $\begin{array}{l}1 \text { corresponds to the highest level } \\
\text { of the Central bank autonomy }\end{array}$ & Arnone et al (2007) \\
\hline Turnover & $\begin{array}{l}\text { Number of central } \\
\text { bank governors per } \\
\text { year }\end{array}$ & $\begin{array}{l}\text { Turnover rate of central bank } \\
\text { governors }\end{array}$ & Crowe-Meade (2007) \\
\hline $\begin{array}{l}\text { Exchange rate } \\
\text { stability }\end{array}$ & Index number & $\begin{array}{l}\text { The exchange rate stability index } \\
\text { ranges from } 0 \text { to } 1\end{array}$ & AREAR 2011 (IMF) \\
\hline \multicolumn{4}{|c|}{ Institutional characteristics } \\
\hline Governance & Index number & $\begin{array}{l}\text { A rating reflecting bureaucratic } \\
\text { quality, corruption, democratic } \\
\text { accountability and law and order. }\end{array}$ & $\begin{array}{l}\text { International Country Risk } \\
\text { Guide }\end{array}$ \\
\hline Regulatory quality & Index number & $\begin{array}{l}\text { Captures perceptions of the } \\
\text { ability of the government to } \\
\text { formulate and implement sound } \\
\text { policies and regulations that } \\
\text { permit and promote private } \\
\text { sector development. }\end{array}$ & World Bank \\
\hline $\begin{array}{l}\text { Labor market } \\
\text { flexibility }\end{array}$ & Index number & $\begin{array}{l}\text { Captures different types of labor } \\
\text { market regulations. Ranges from } \\
0 \text { to } 10 \text {. (Higher values denote a } \\
\text { more flexible labor market.) }\end{array}$ & $\begin{array}{l}2011 \text { Economic Freedom } \\
\text { Dataset }\end{array}$ \\
\hline
\end{tabular}

